$$
\text { بسم الله الرحمن الرجير }
$$

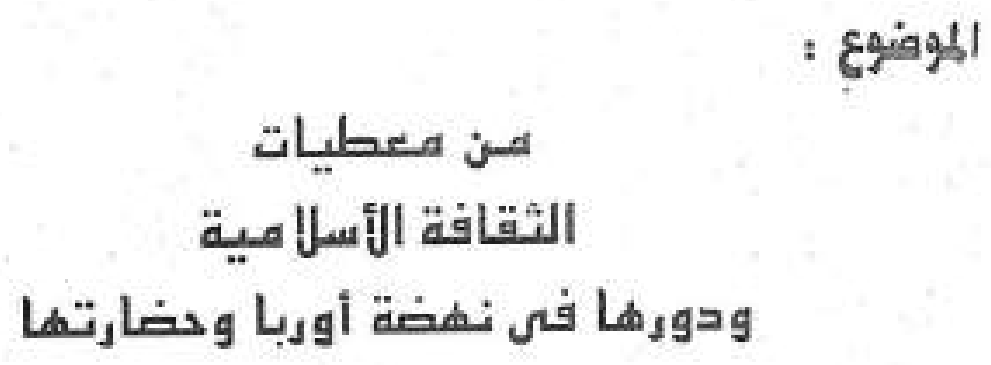

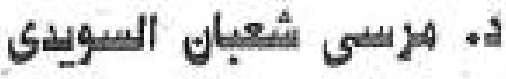

هدرس الدعوة وإلثّافة الإسلامية

بكلية أمبل الدين والدعوة بالمتوفية 


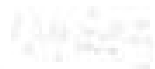

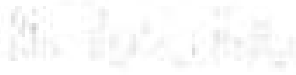
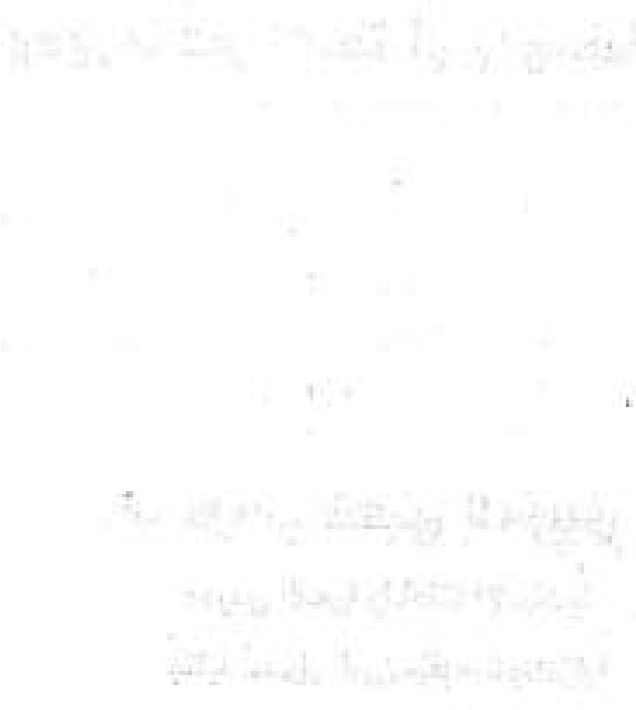


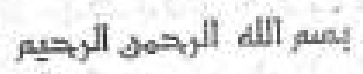

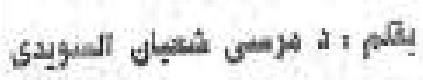

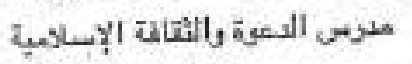

\section{Exiloso of}

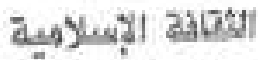

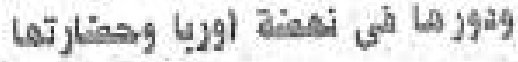

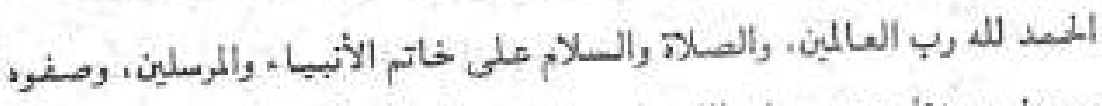

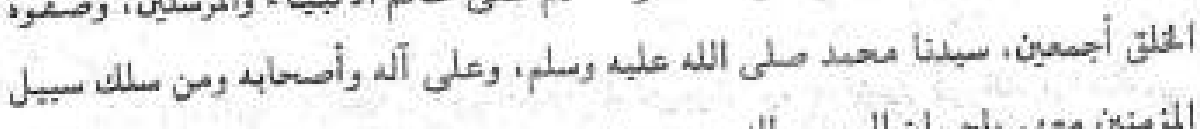
الموتين معبم بإحسان إلى يوم ألدين. وبعد:

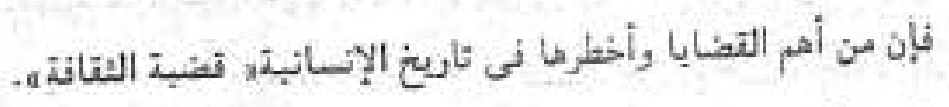

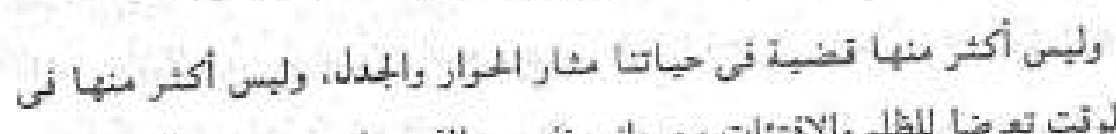

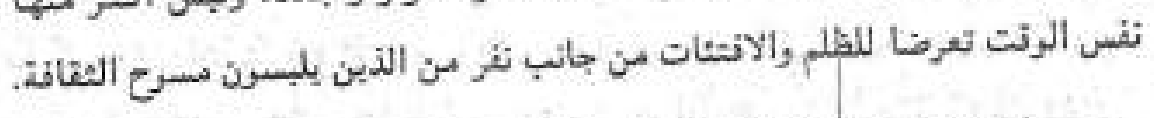

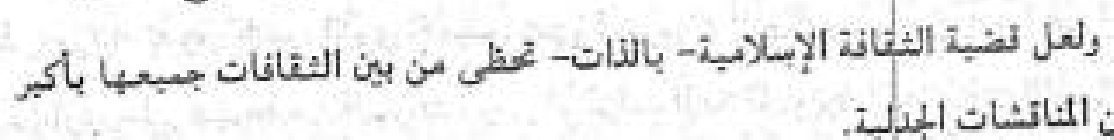

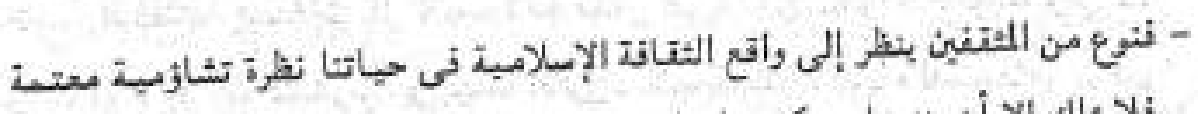

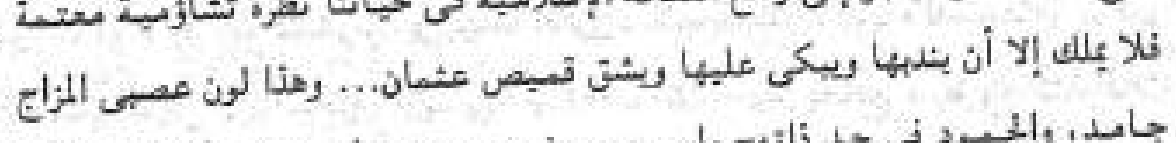

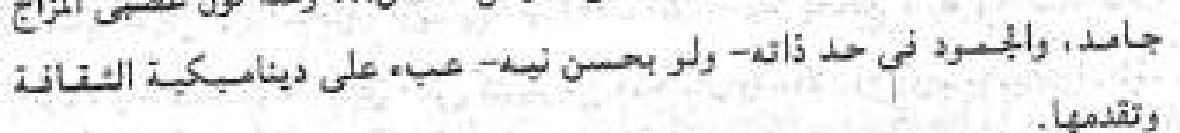
وتقدمبا.

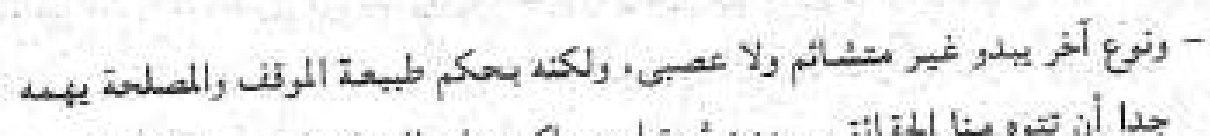

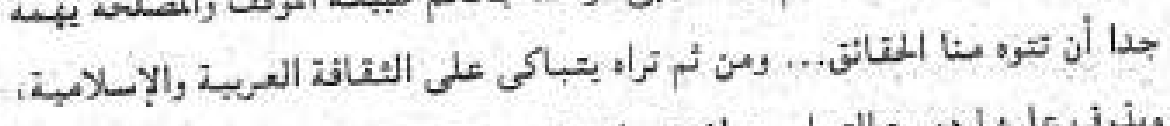

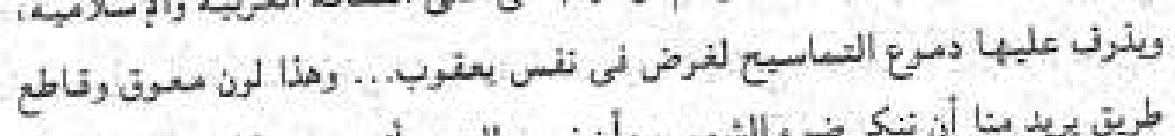

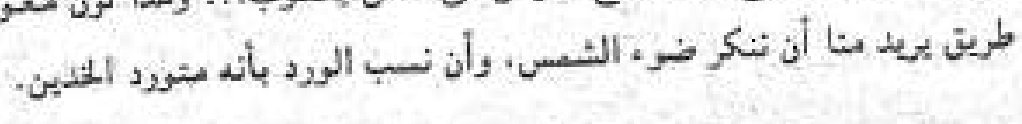


rra

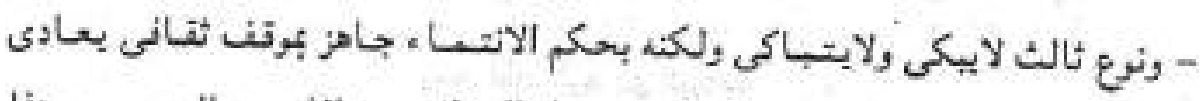

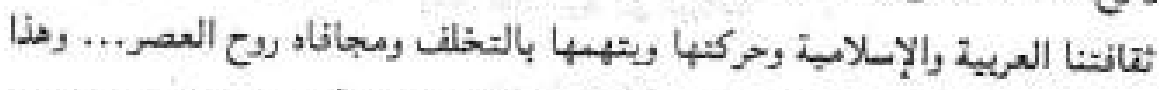

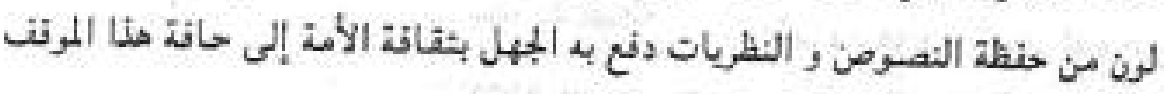

وكل هوزلا، الجامدين والمعودين وعفظة النطريات هم الذين بكئ أن نطلق علبه

بالمنهرم المديث أسم "قرى الثقافة المضادئ"

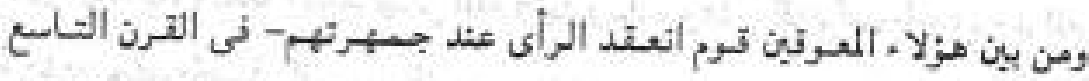

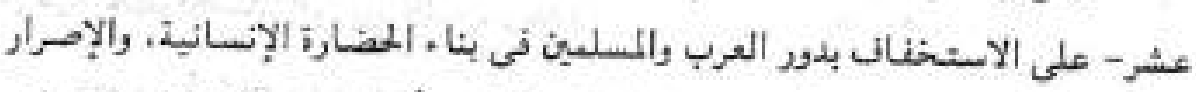

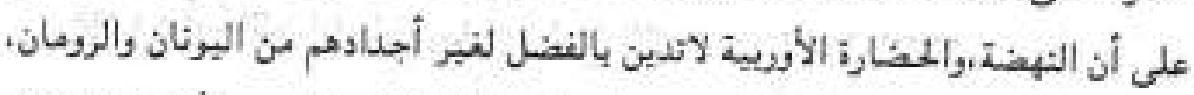

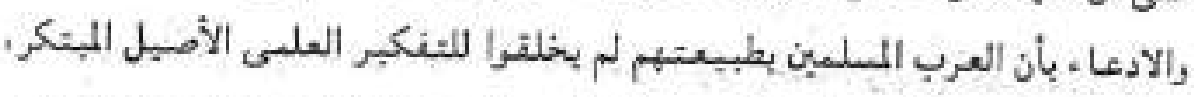

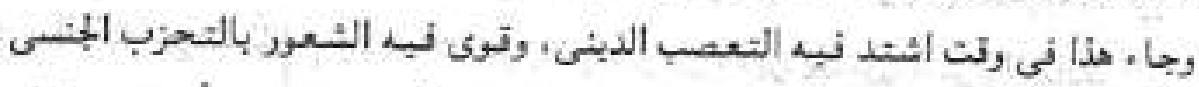

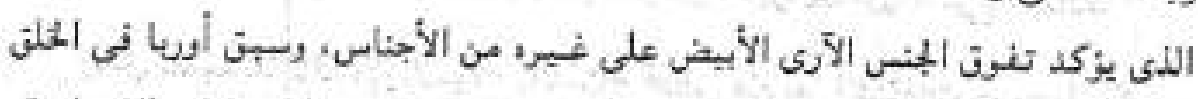

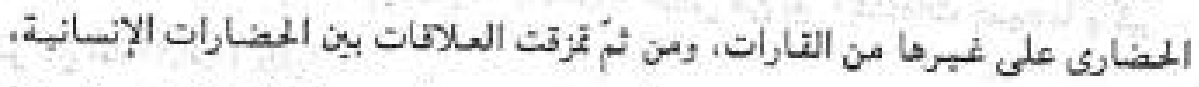

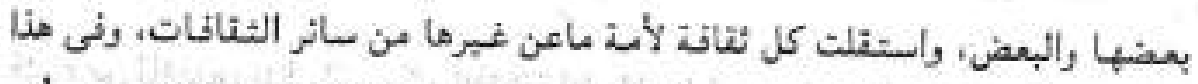

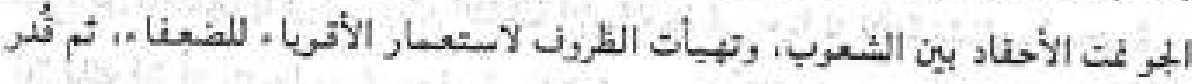

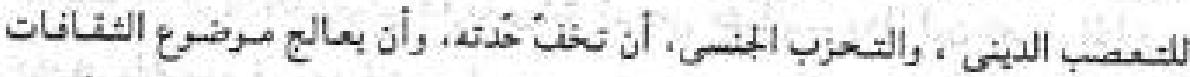

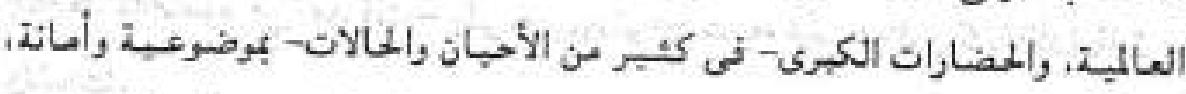

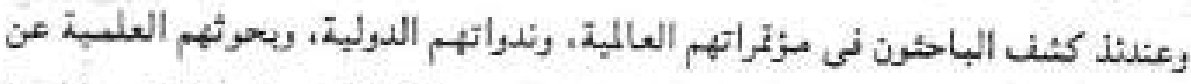

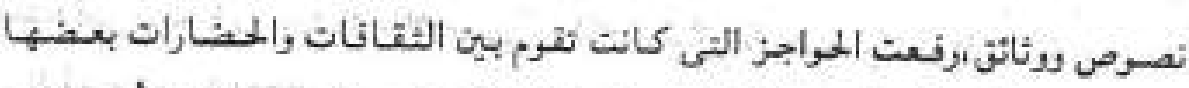

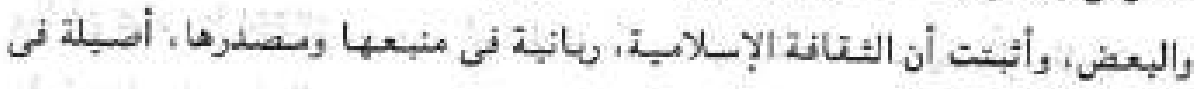

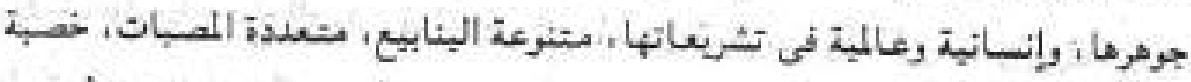

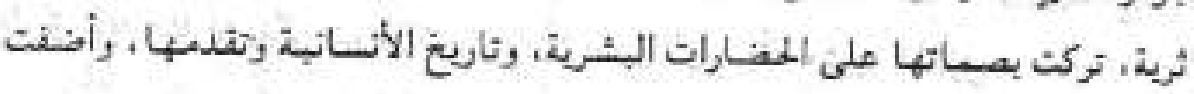




\section{rra}

على التفكير العلمى حركّة تبعث نيه الحياة ،وتسمو يه.

ولقد تجلت اليقاقة العربية الإملامية بختمالف تروعها ومعطياتها ، وألفت جانبا

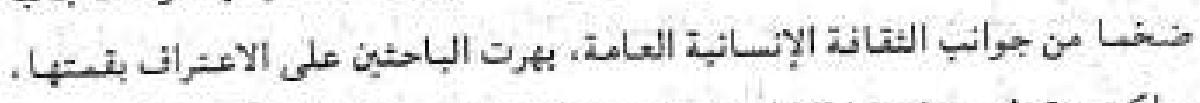

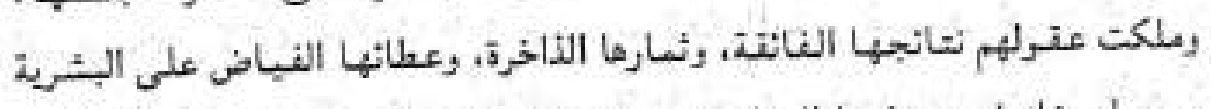

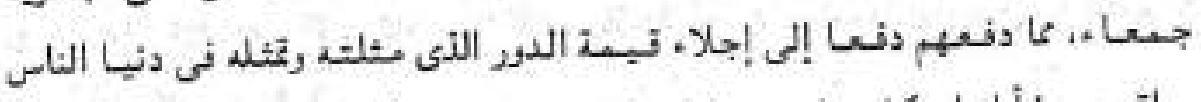

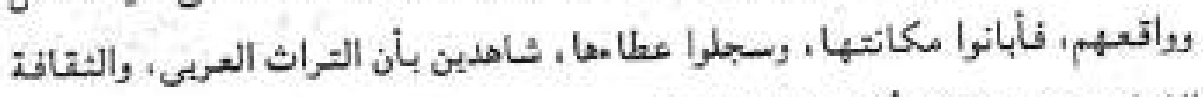

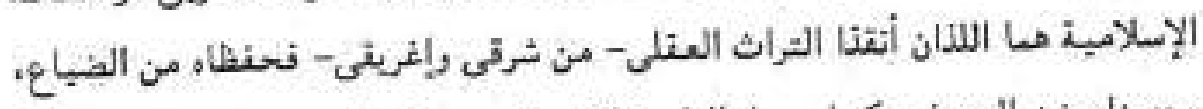

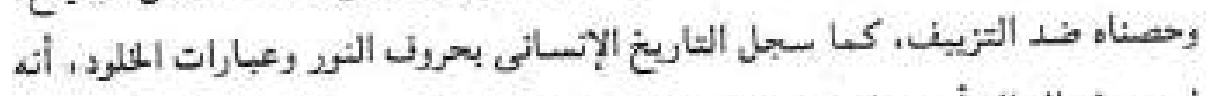

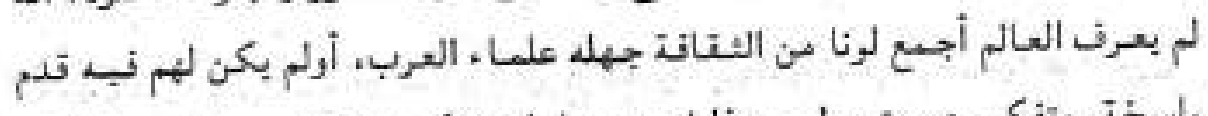

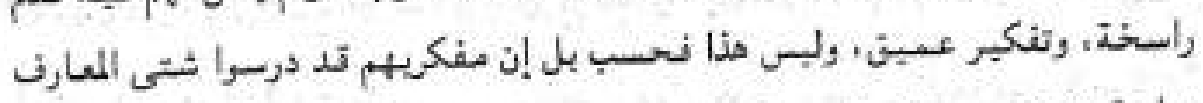

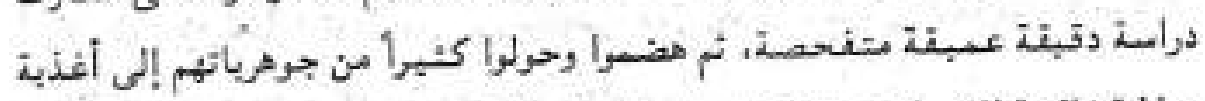

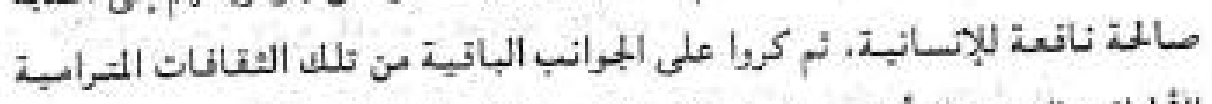

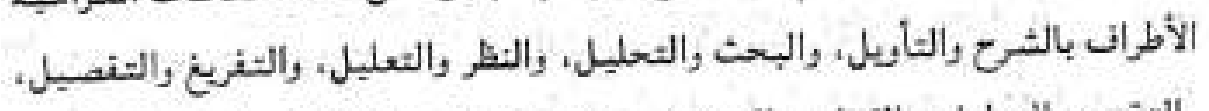

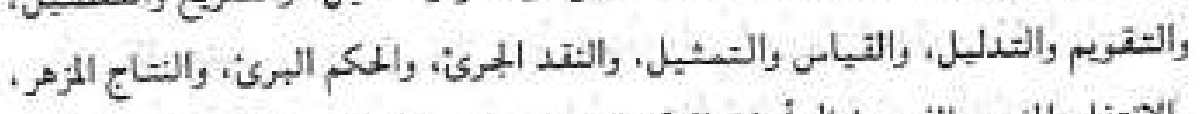

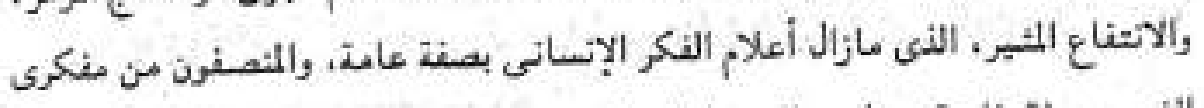
الغرب بصفت خاصة، ينظرون إليه تظريات الإعباب والاستحسان. وهاهى بعض شهاداتهم وهى تجلى نضل العرب على المضارة الإتسانية بأسرها،

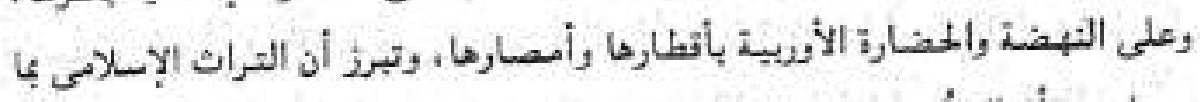

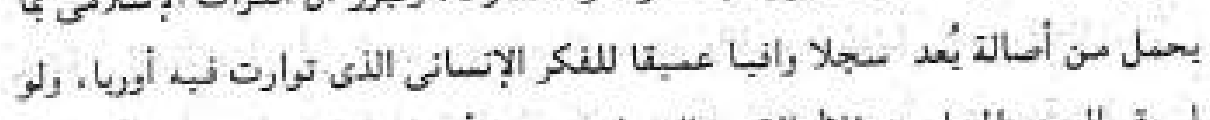

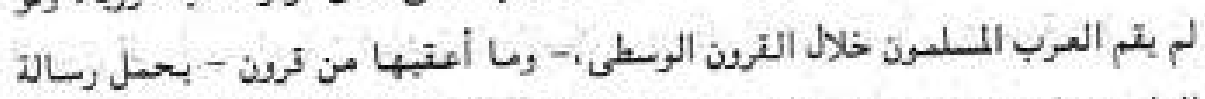

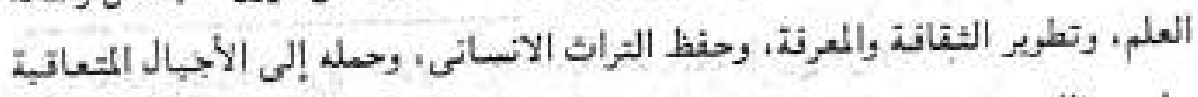
على مر العصور ماقامت فى الديبا هذه النهضة العلمينة. 
re.

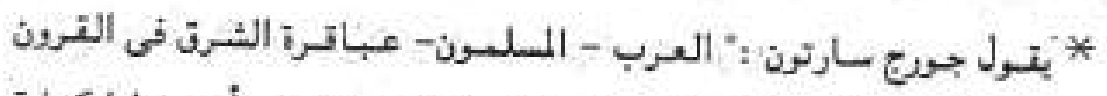

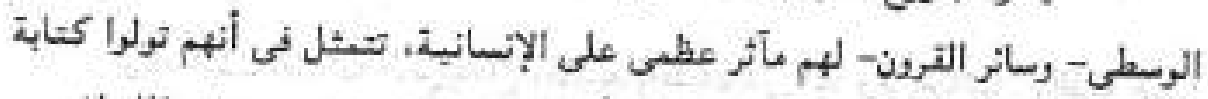

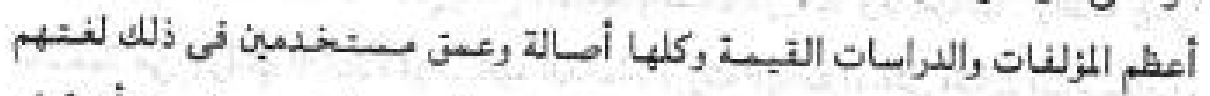

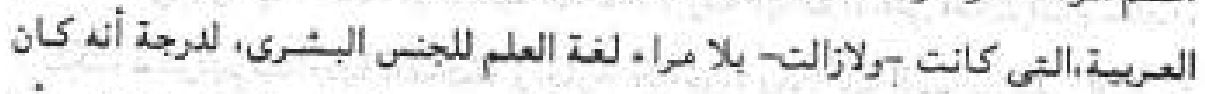

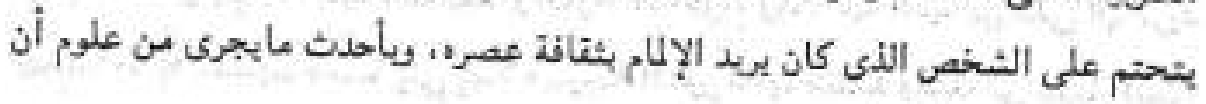

(1) يتعلم اللغة العريبة

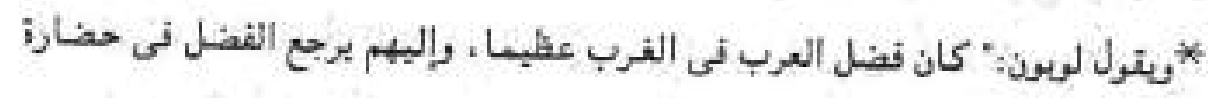
أوربا"

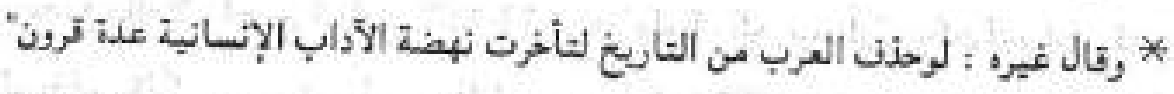

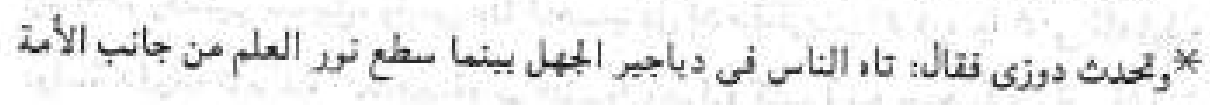
الإسبامية سن علوم ورلسفة وصناعة وآداب...

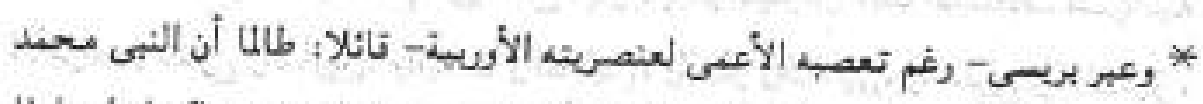

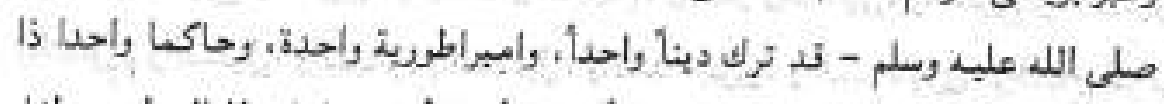

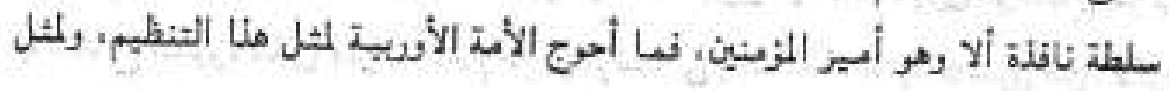

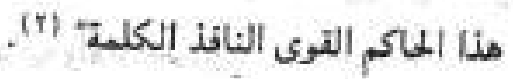
* ويقول الأستاذ وكريبستر فرواوب :عن العرب أخذت التقاليد العلية في أوريا

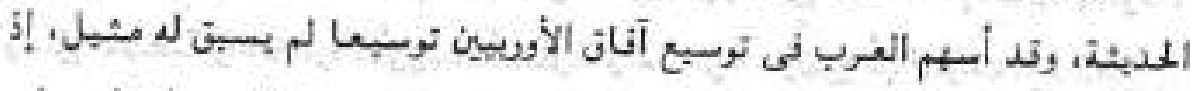

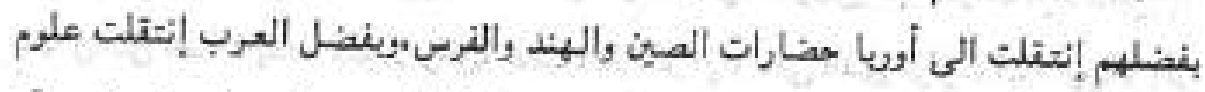

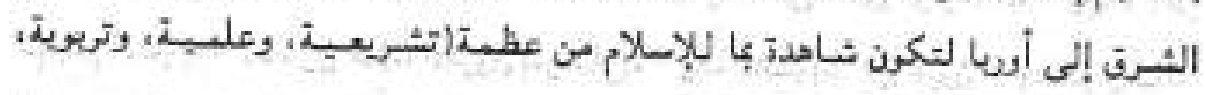

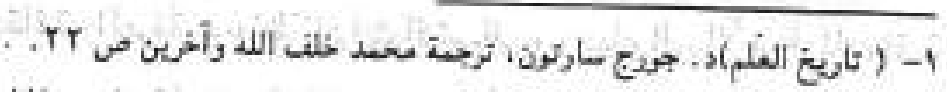

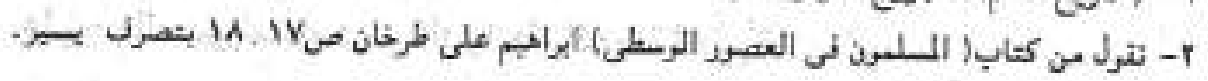


واجتماعية، واتثصادية..) ، وفضل على الإتسان والإتسانية جمعا،:11)

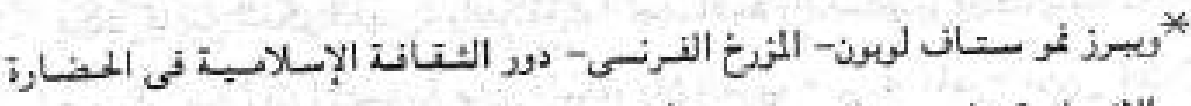

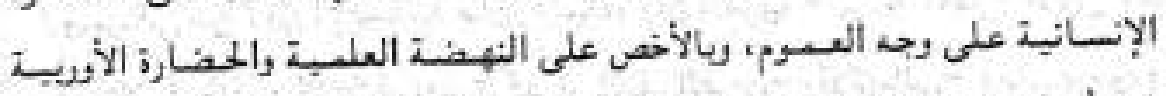

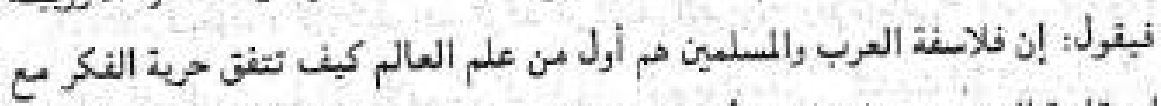

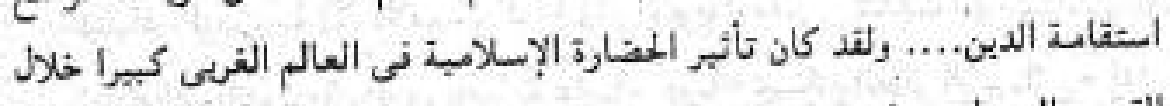

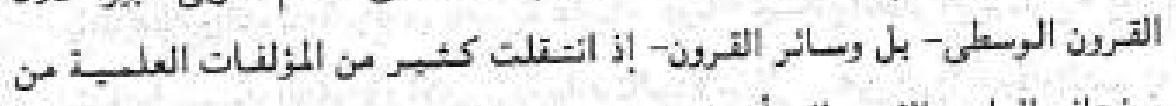

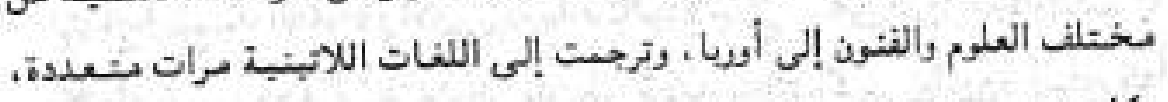

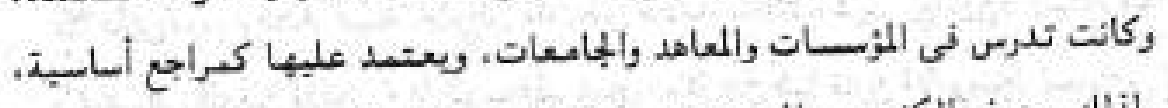

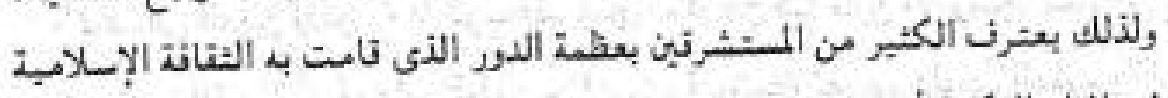

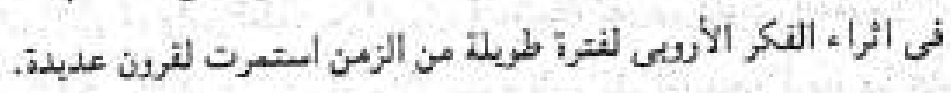

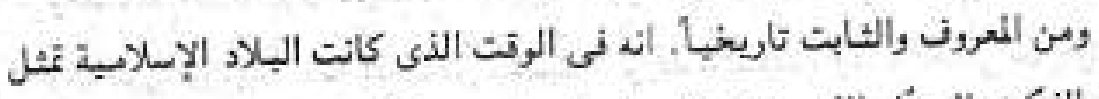

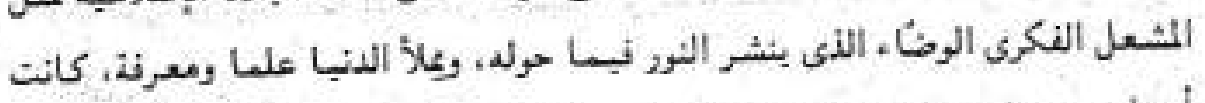

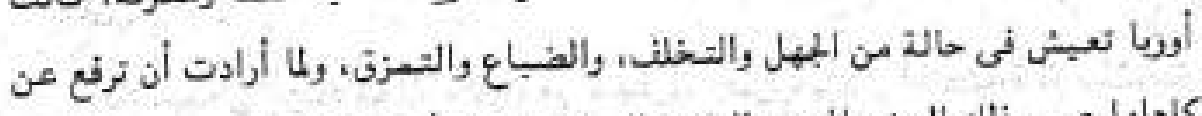

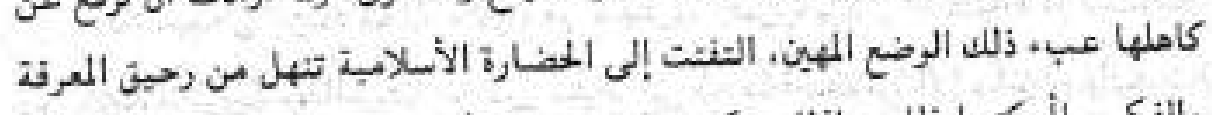

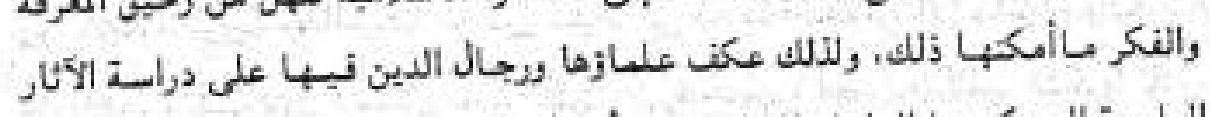

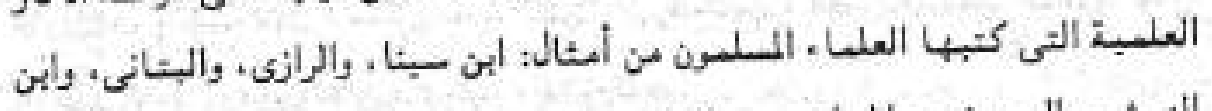

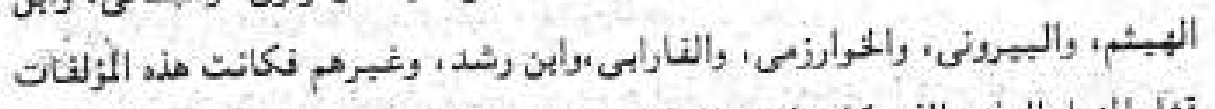

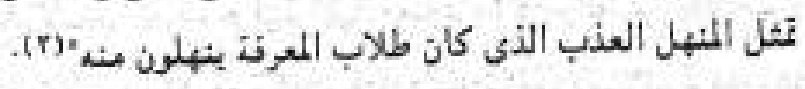

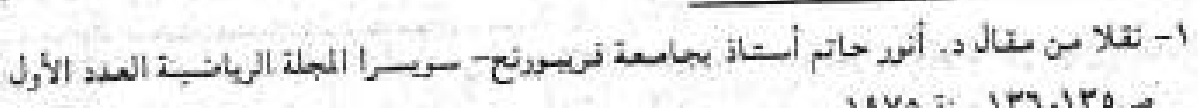

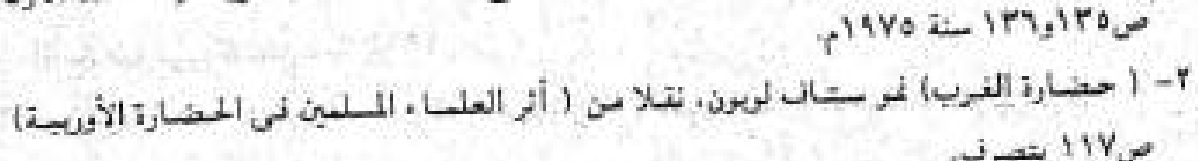
مان 
* وأجلى الدكتور كويلر بونج - أستاذ العلاقات الأجنيبة في جامعة برنستون بواشتطن

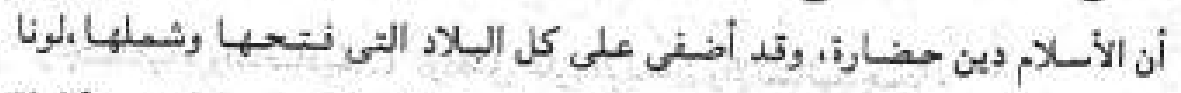

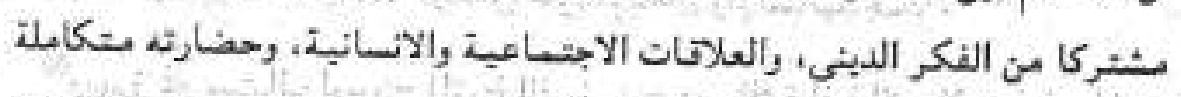

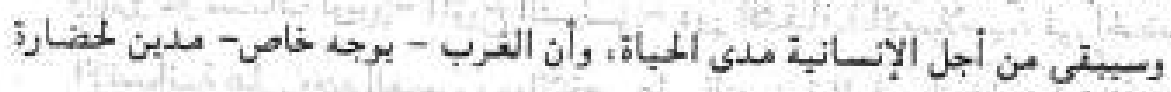

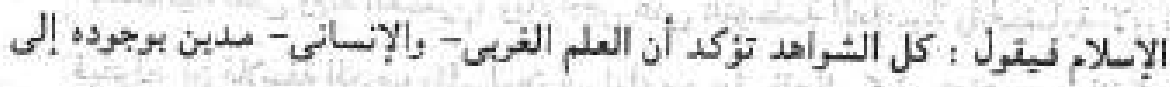

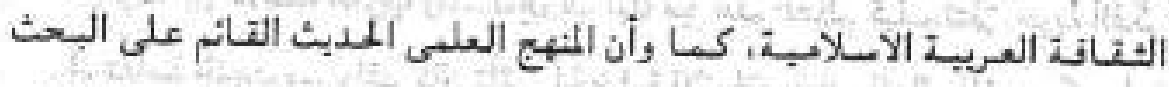

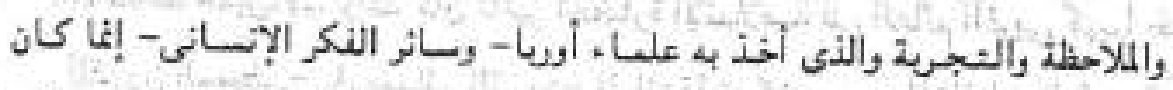

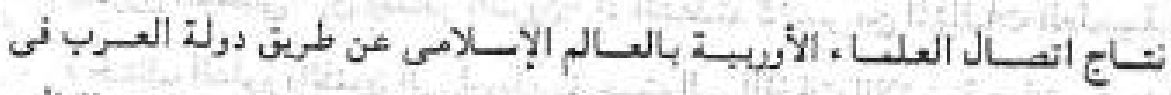

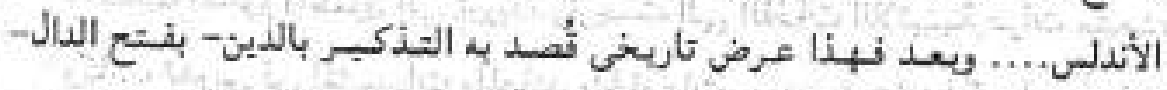

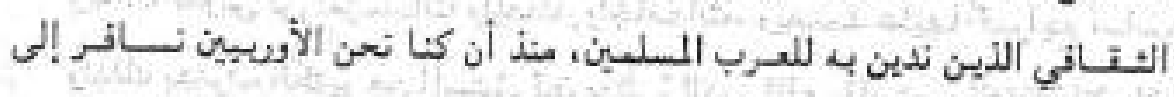

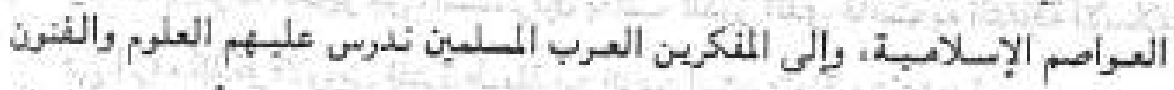

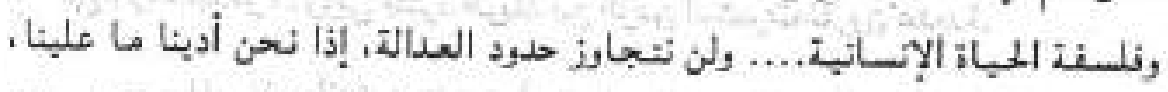

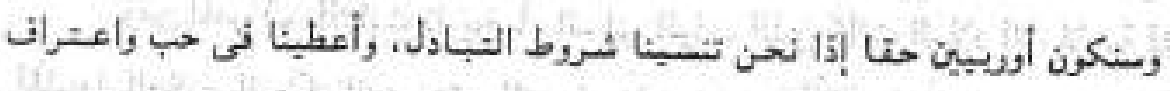

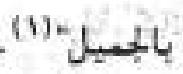

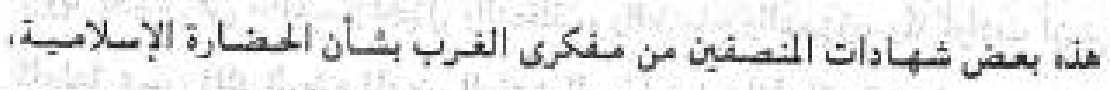

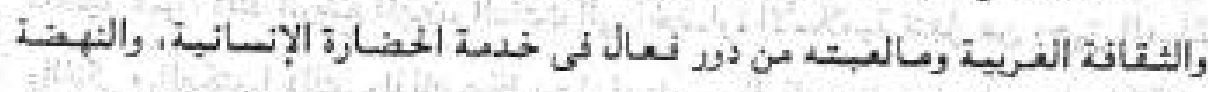

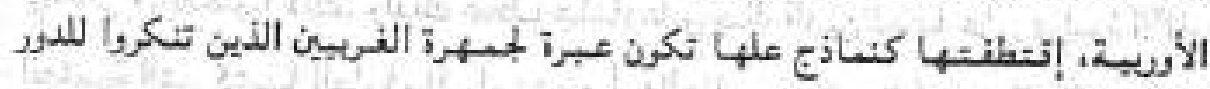
العلىى العيى ومآثره على نهضتهم وحضارتهم.

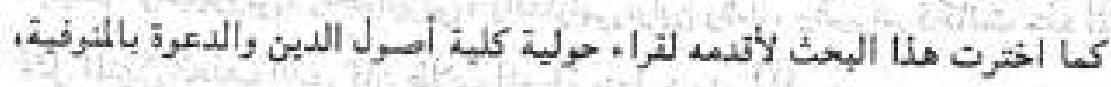
وهو منتخب من مادة علمية جستها وكتبثبا تحت عنوان الثقافة الإسالاية ودورها

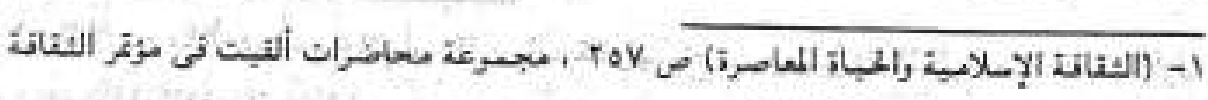

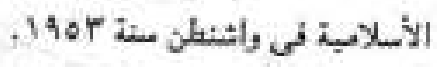

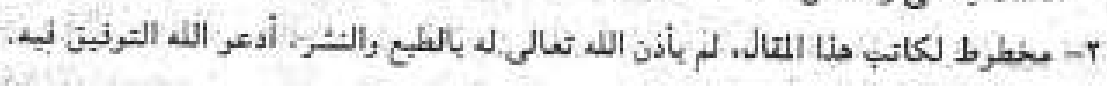


rer

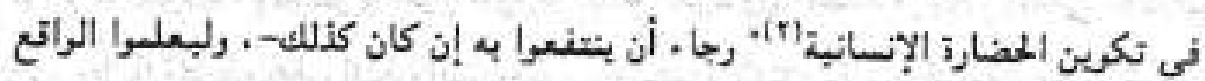

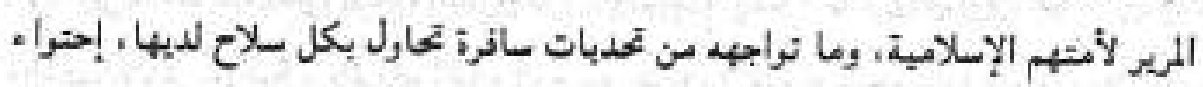

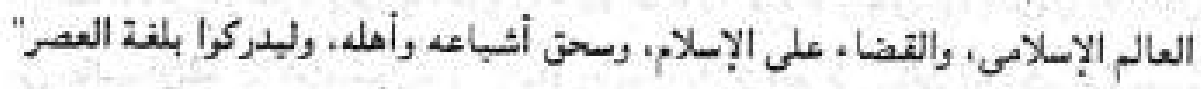
المصدر من العالم الإسلاسى لشتى أنحاء المعبورة، وخاصة أوربا، والمستورد مثها إليه.

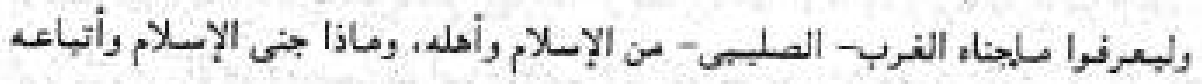

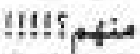

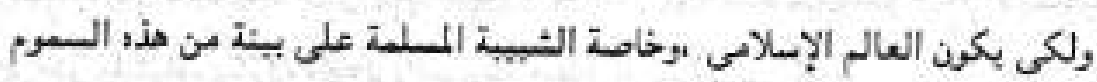

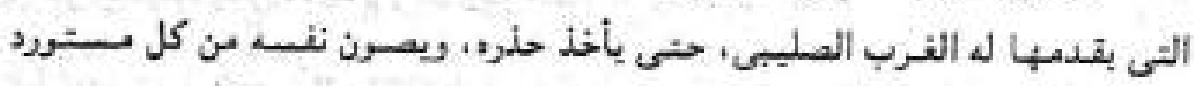

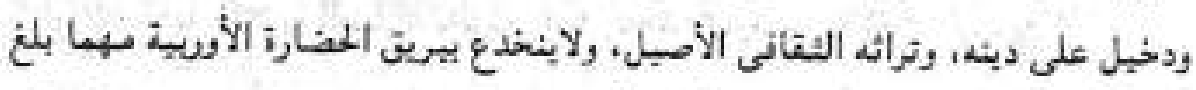

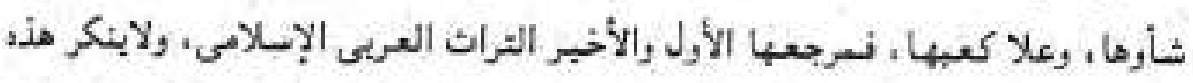
المتيقة العلمبة إلاسكاير، ، ولا بحجدها إلا معاند.

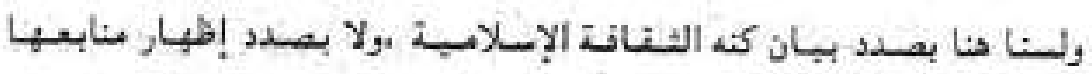

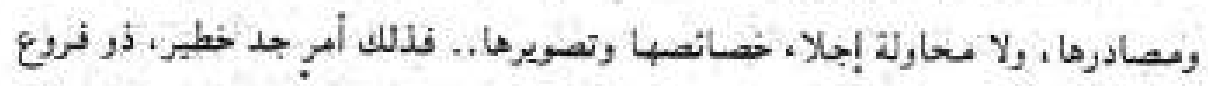

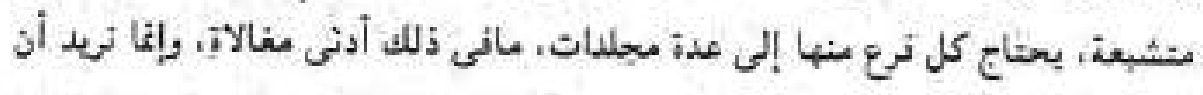

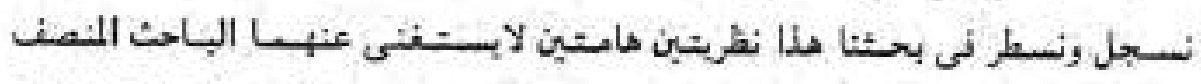

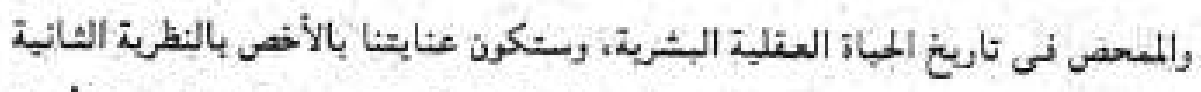

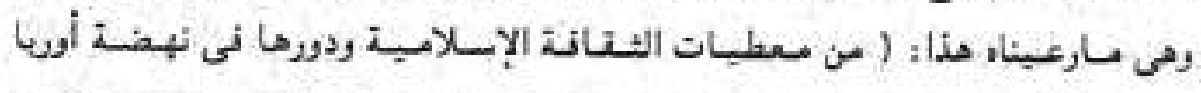
حضارتها).

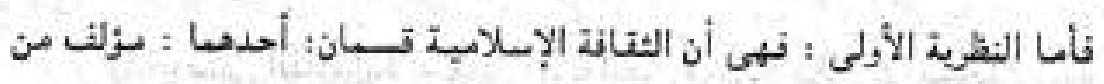

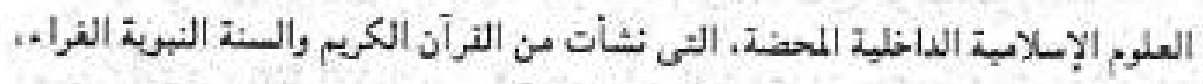

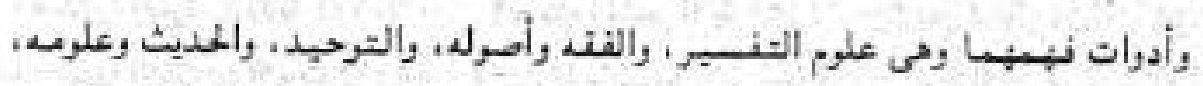

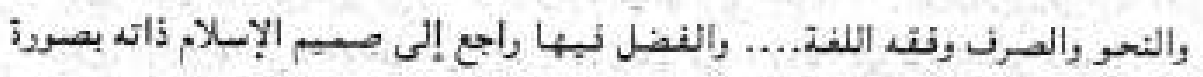

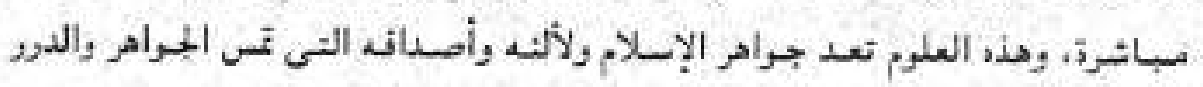




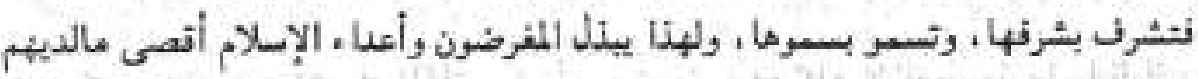

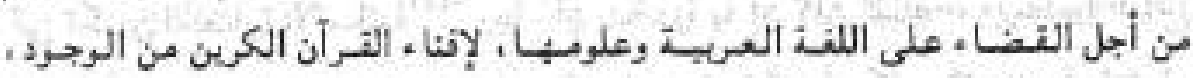

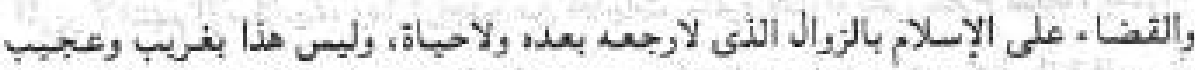

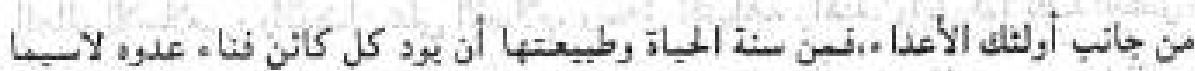

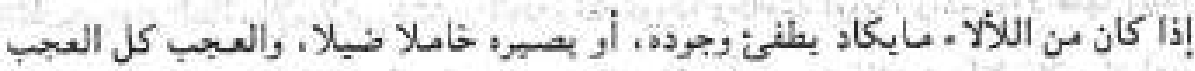

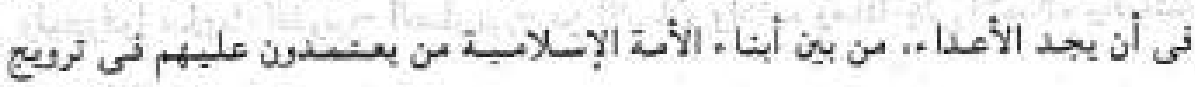

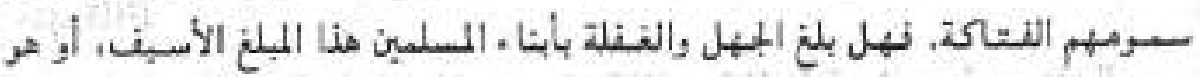
الغدر والخياند وشراء الذيم واستئجار الضمائر والأثندة ؟!!...

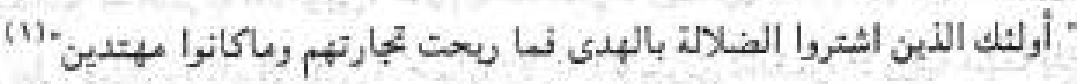
ولن يصلو ليغيتهم. لأن الله تبارل وتعالى قد تكفل بحفظ ويته ورغاية أتباعه.

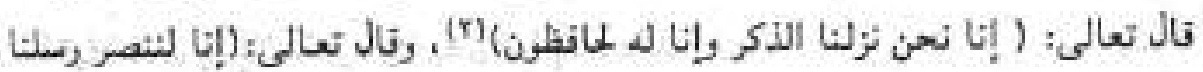

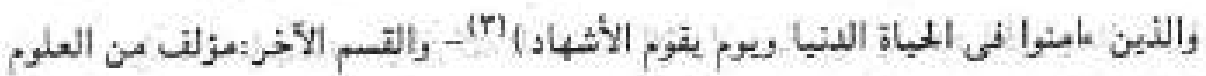

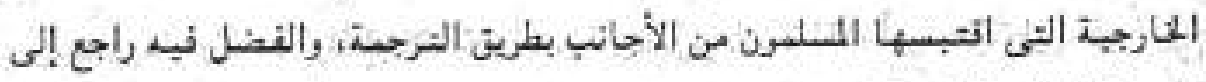

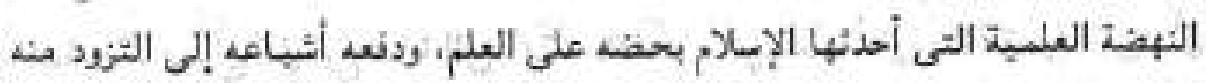

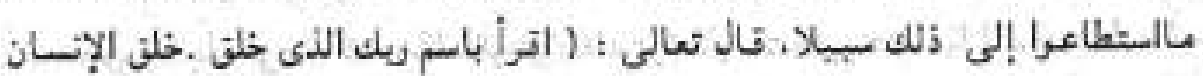

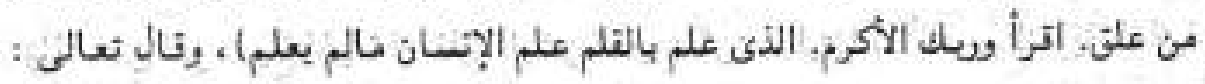

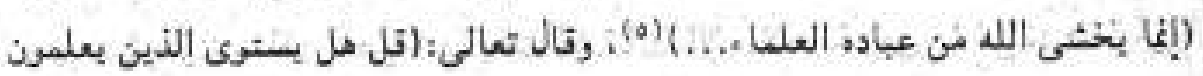
والذين لابعلمون)(1)، والآيات كثيرة.

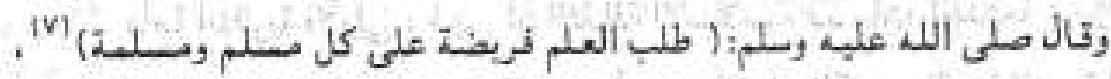

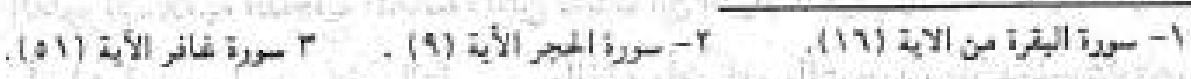

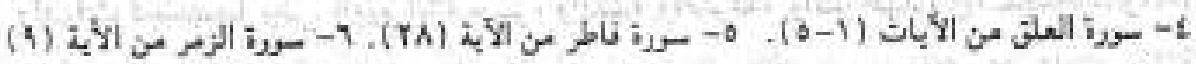

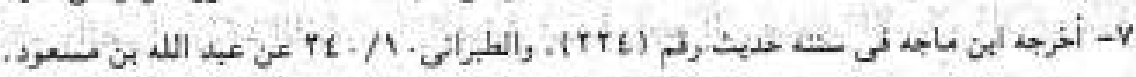


re

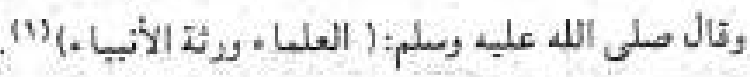
وتال حلى الله عليه ورسلم:ا تعلصوا العلم، فأن تعله لله خشيه، وطلبه عيادة،

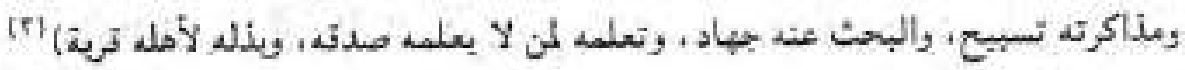
وأما النطرية الثانية التى نود تسطبرها في بحثبا هذا فهى بيان مآثر العرب

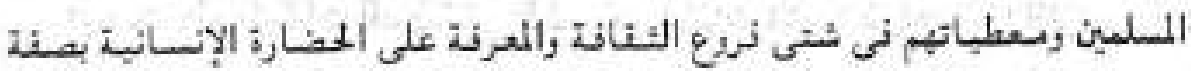

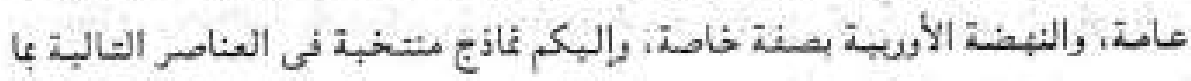

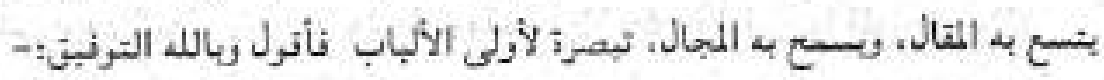
وأهمم العناصر التم سنجليها بصفة هبرملة:-

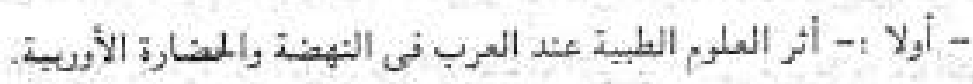
- ثانيا :- دور العلوم الرياضهة والطبيعية عند العرب نى اللخضارة الأربية.

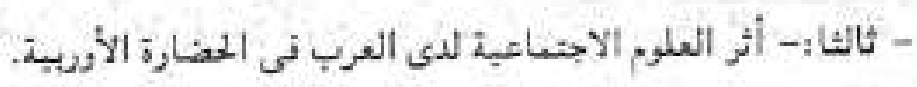

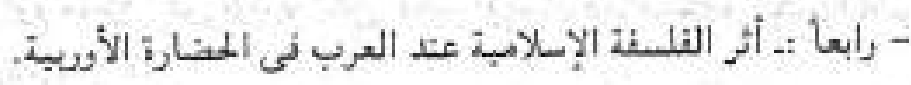
- خامساً :- أثر الأدب العبى عند العرب فى الحضارة الأبربية.

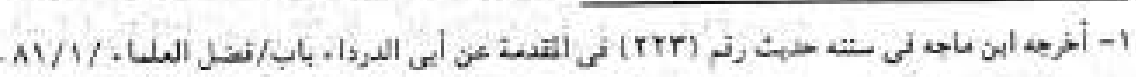

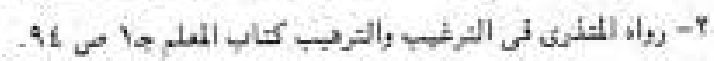


لتد كان للعرب دور بارن فى تكويت التفكير العلبى فى أوربا ، وخاصنة نى

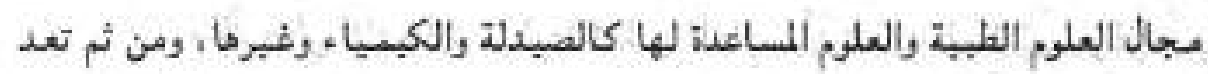
هذه العلوم من أبرز المعالم التى عنن بها العرب عناية كيرةًا، واستطاعوا أن يكتشفرا

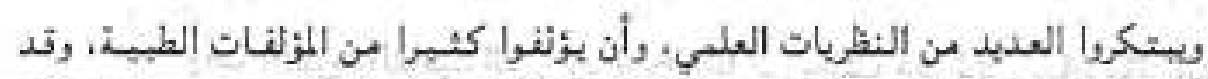
ترجمت هذر المؤلفات التريبة فى الطب إلى اللغات الأوربية واهتم بها الغريبون أتصاما

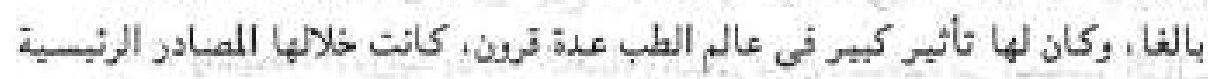

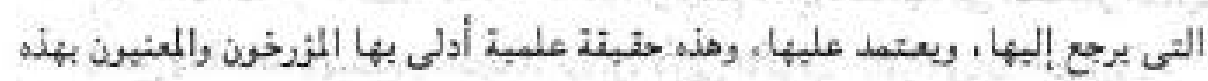

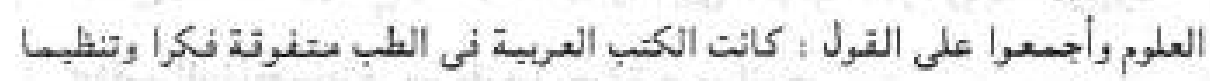
وتنسبقا على جميع ماكتب خلال القرون الوسطى + وتذ أفاد الفريمن من هذه المؤلفات

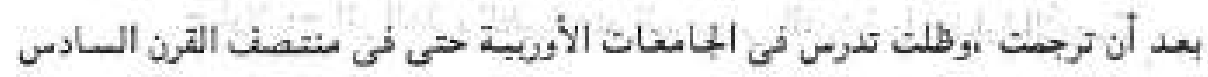

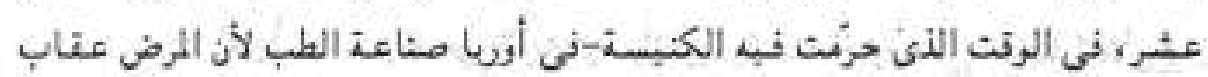

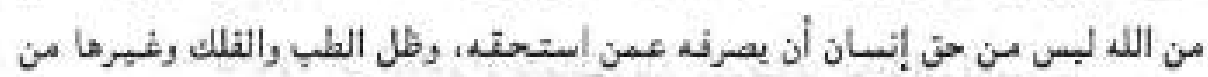

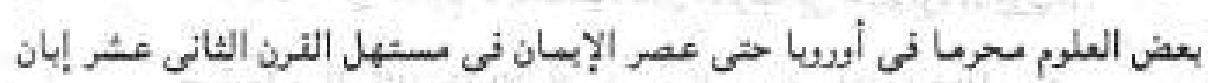

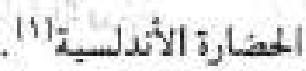

وهاهي بعضى ثبادات علماتهم وهى تؤكد دور العلوم الطبية لدى العرب فى

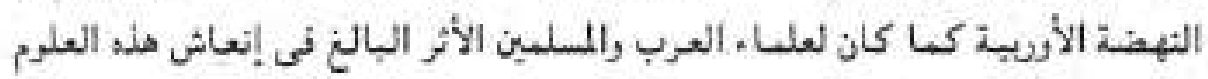

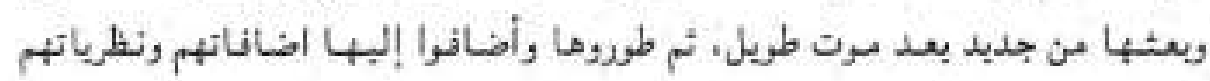

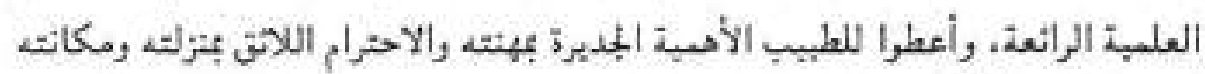

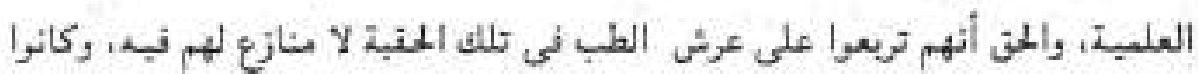

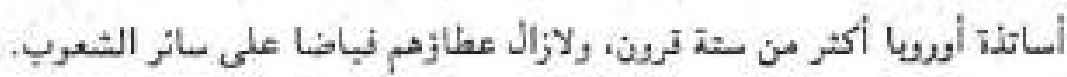

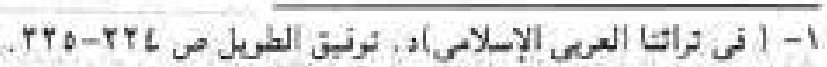




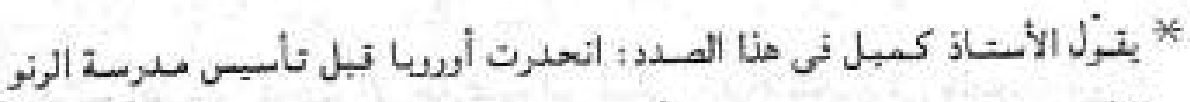

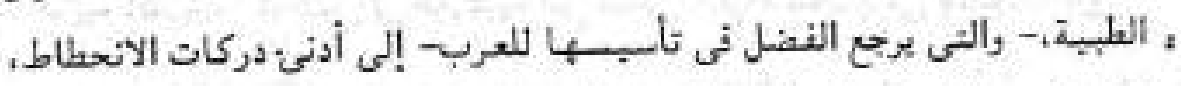

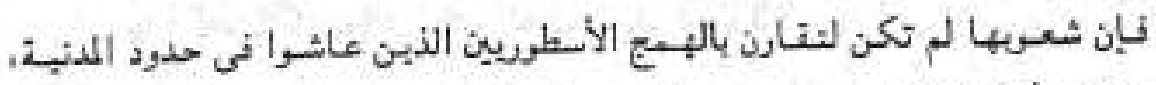

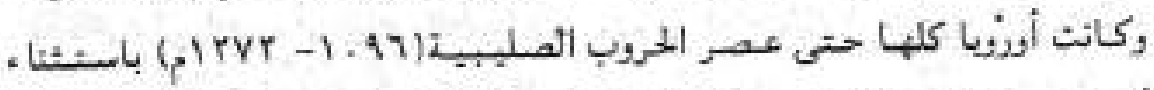

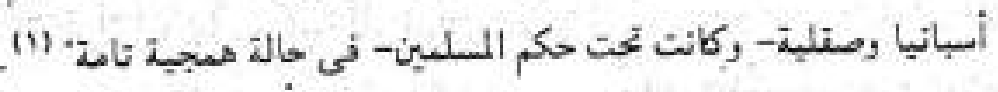

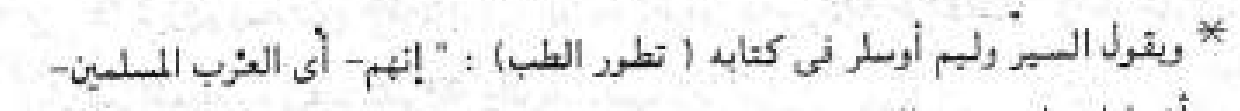

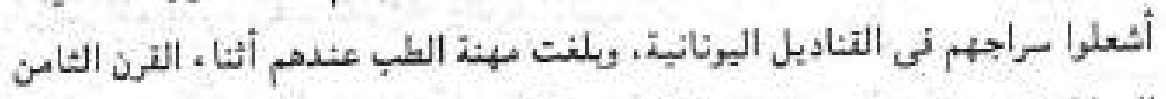

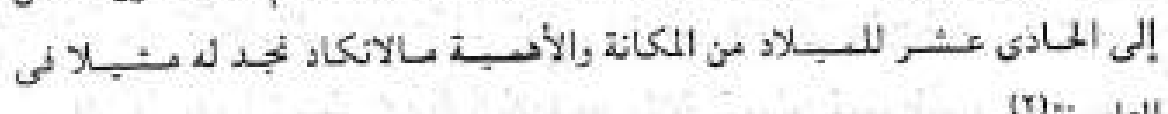
التاريخ "(r)

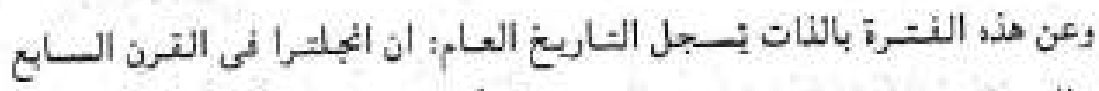

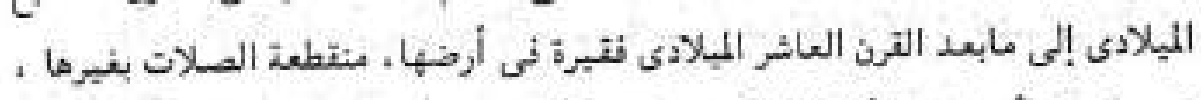

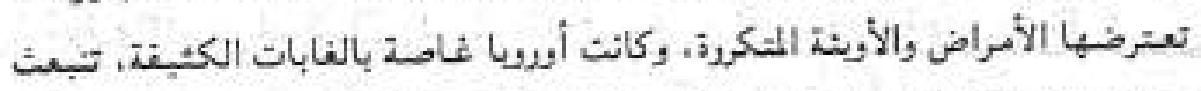

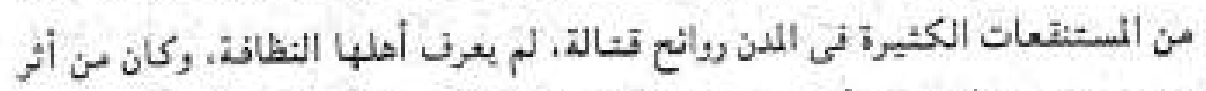
ذلك - كسايقول درابر: أن مست المببالة أوريا وساورتيا الأوهامب.... وبات الطب.

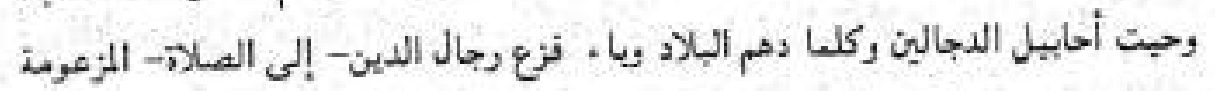

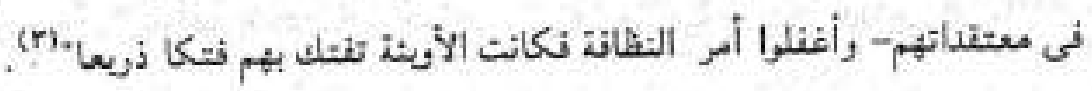
ولقد عرف علمأ الغرب الطب- بعد ائتشار الإسلام نئيجة الثترحات الإسلاهية

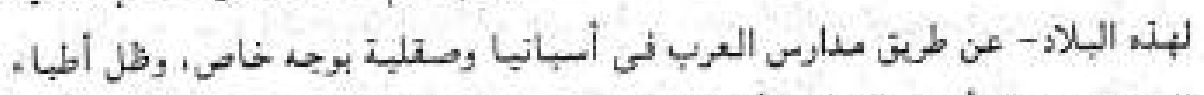

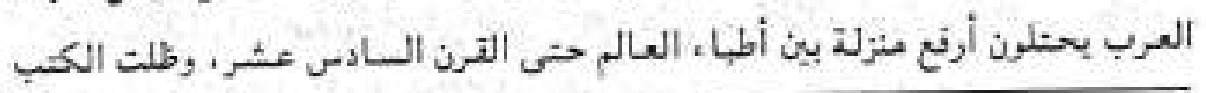

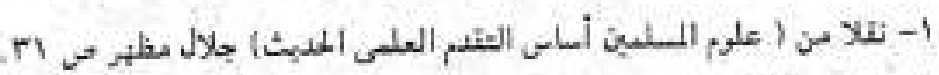

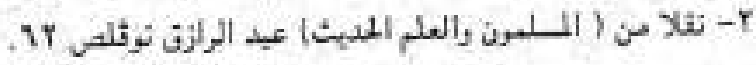

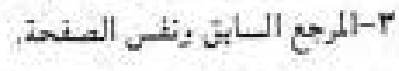


الطيبة العريمة المثرجمة إلى اللاتهينية هى أساس المعرقة الطبية في جاسعات أوروبا.

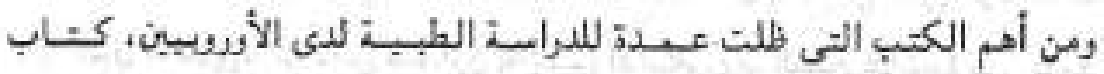

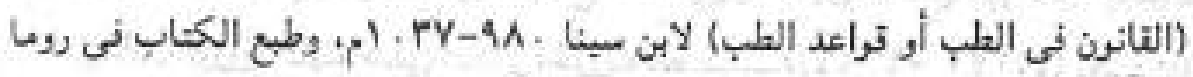

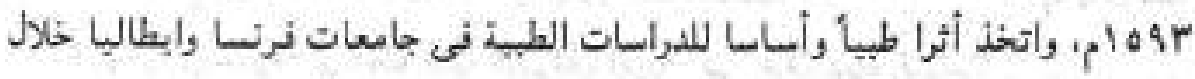

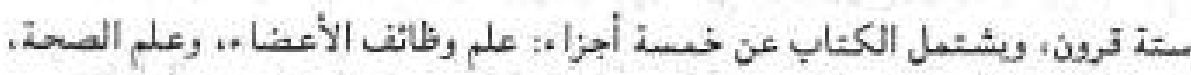
(1) رعلم الأبراض، وعلم المعالجة، والماوة الطبية. * أعظم جراحى المسلعين هو أبي التاسم القرطبى الشهير بالزهراوى، له كتاب يدعى

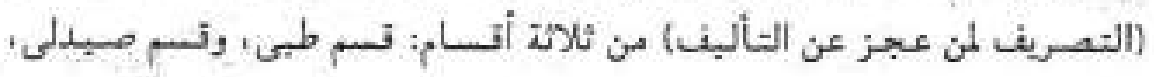
وتسمبم جراخى.

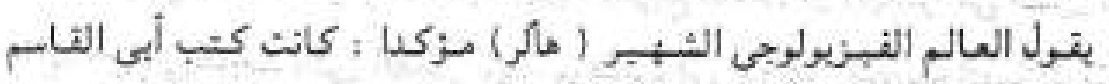

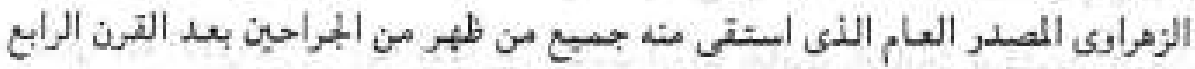

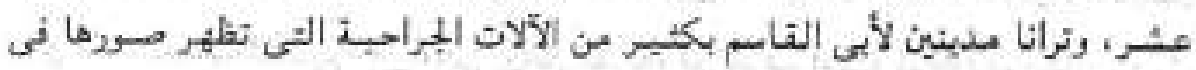

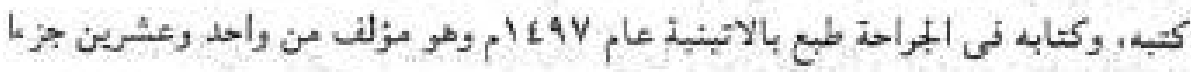

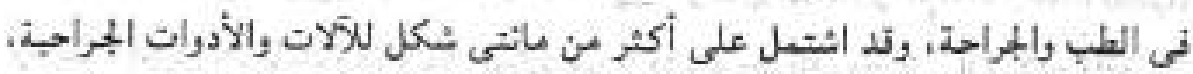

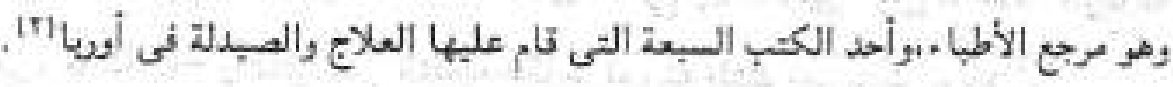

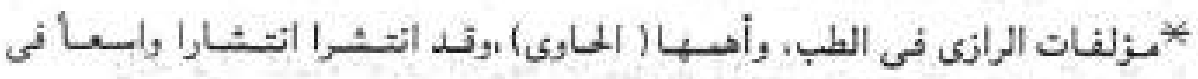

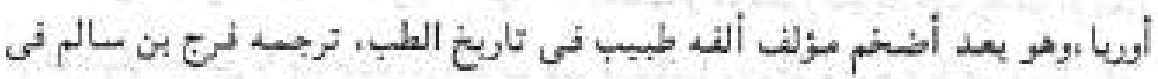

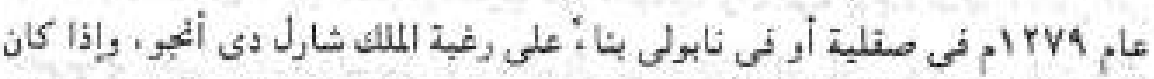

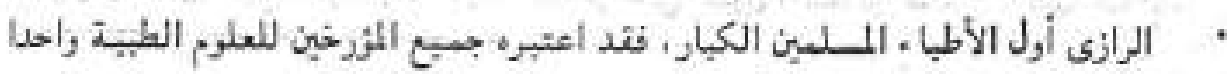

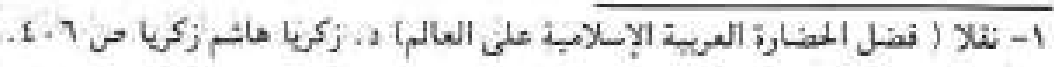

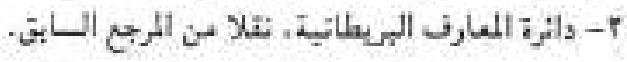




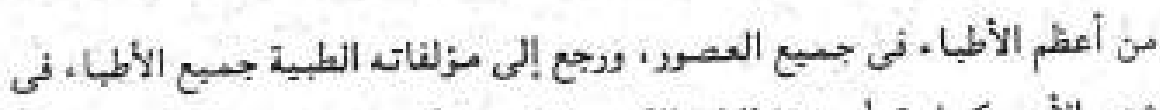

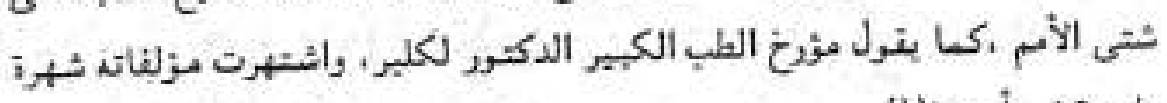

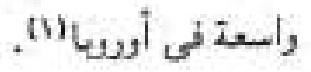

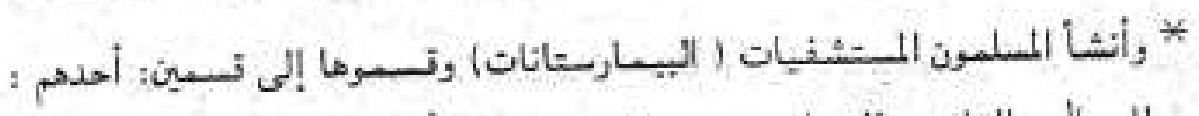

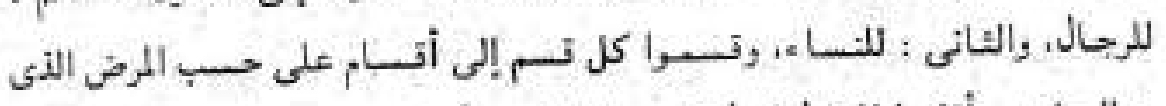

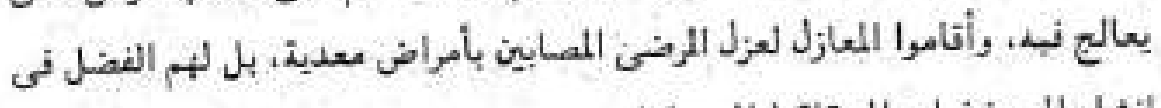

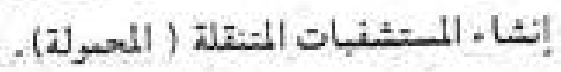

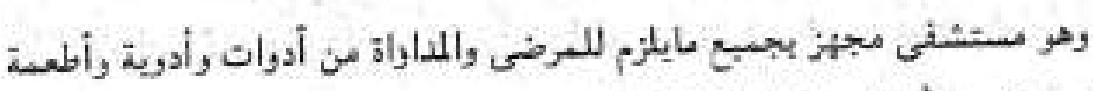

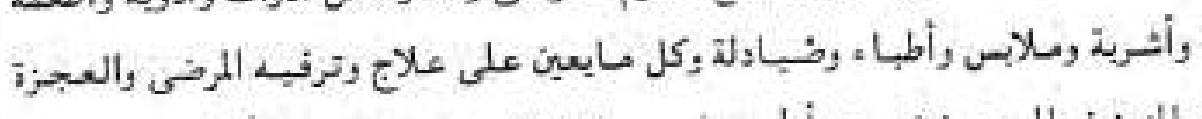

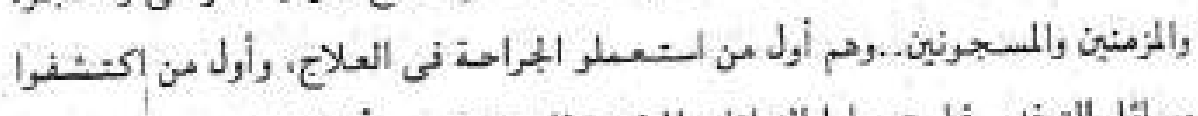

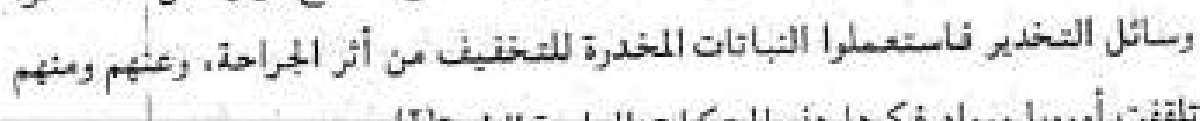

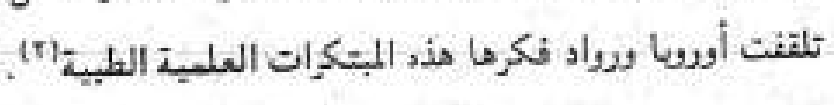

وإذا ذكر البب رقاداته وعلماته فجديرينا أن نبرز علم من أعلام الأسلالم وهو:

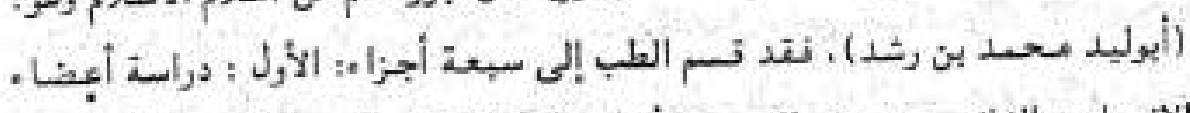

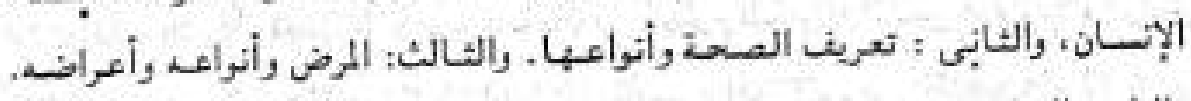

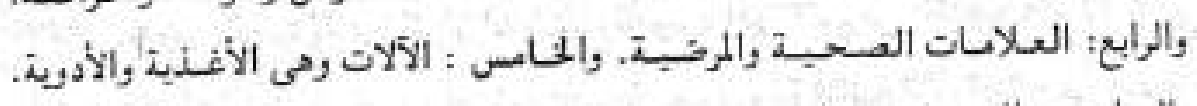

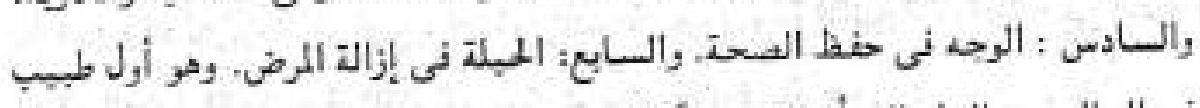

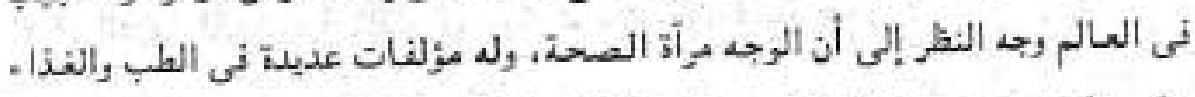

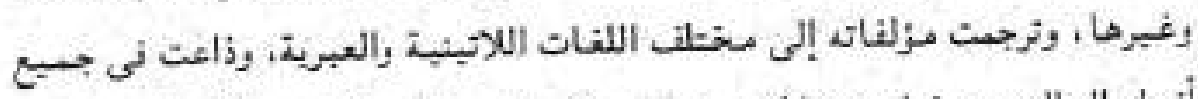

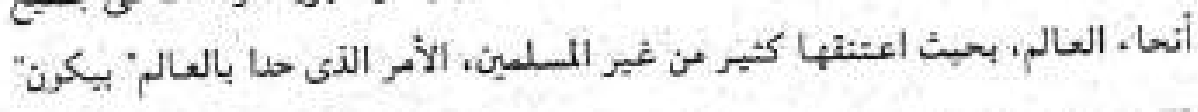

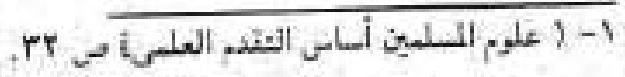

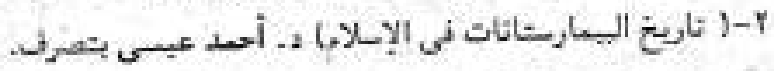


ro.

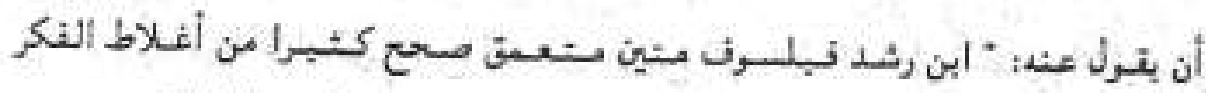

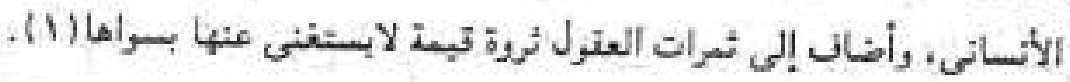

: الصيدالة ( علم الادوية) عثدالعرب :*

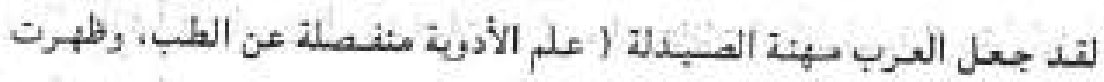

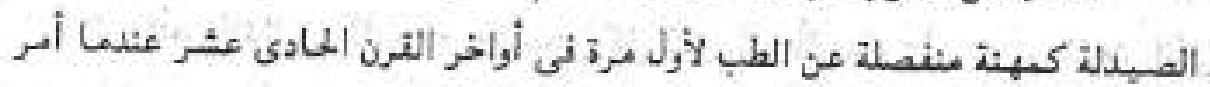

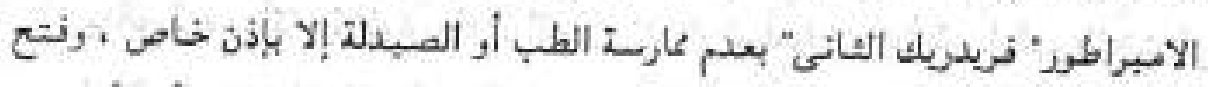

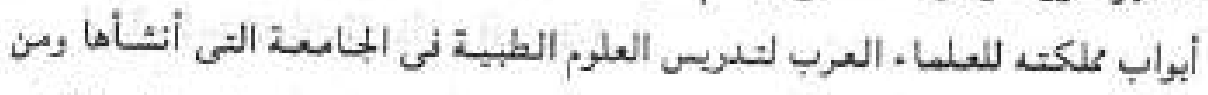

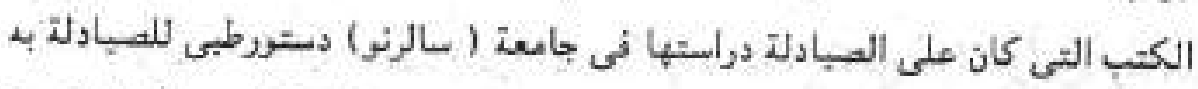

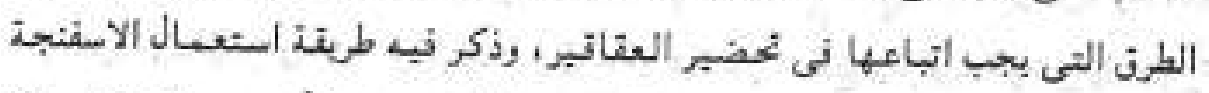

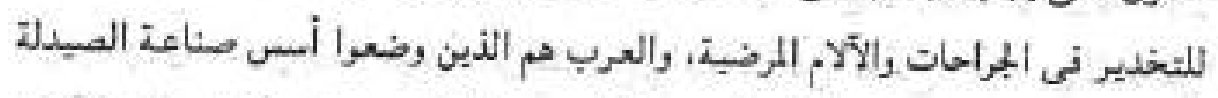

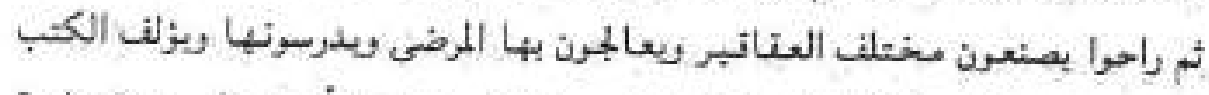

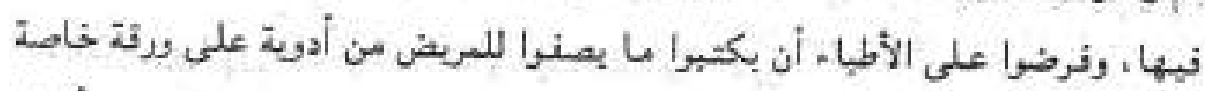

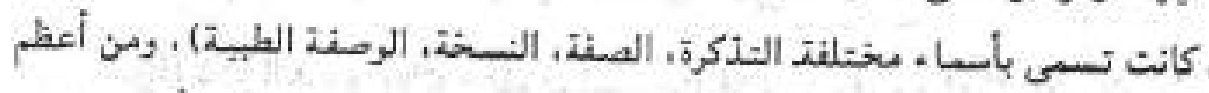

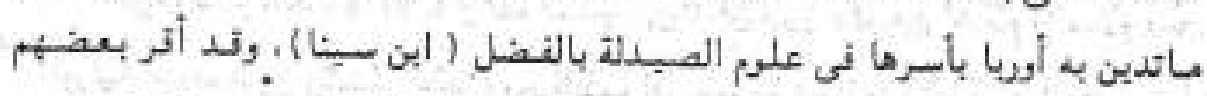

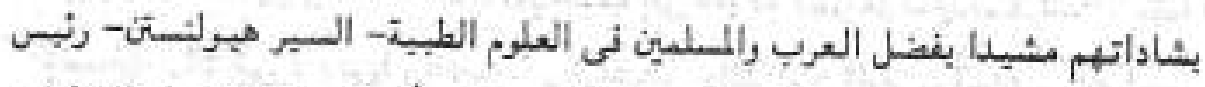

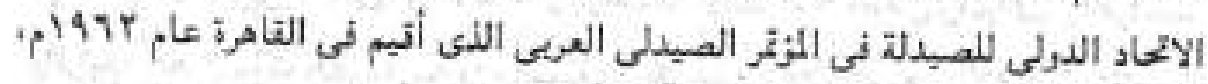

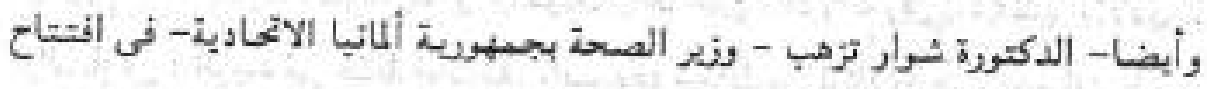

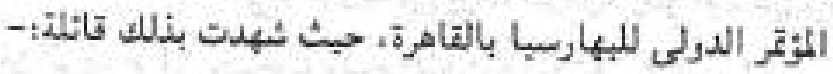

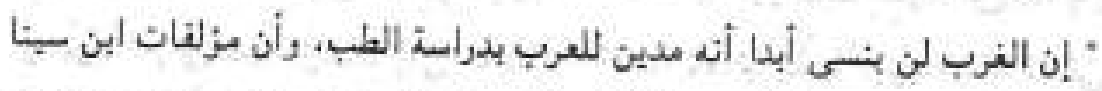

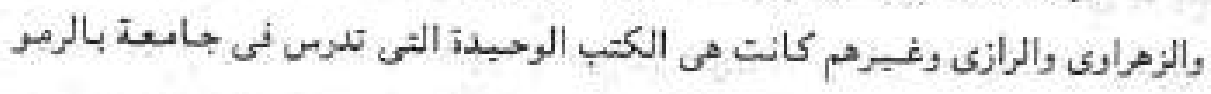

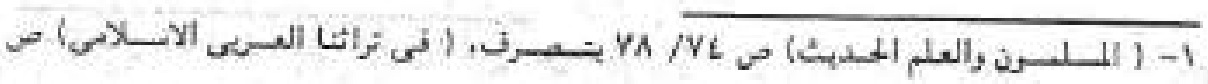
' 


\section{rol}

(I)"التى أثهر ملرسة للطب في العالم الغيى

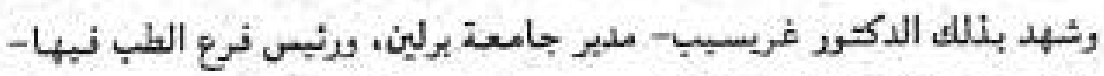

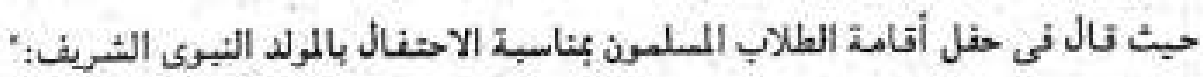

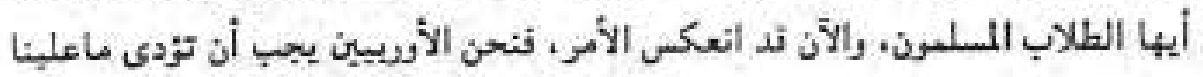

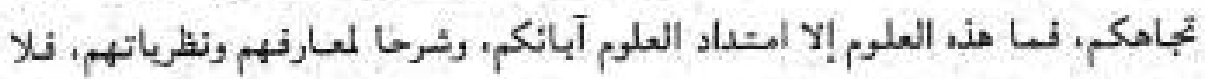

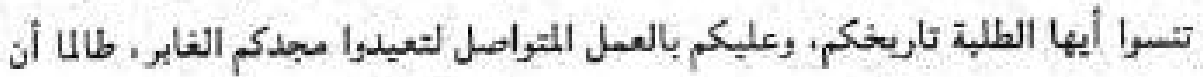

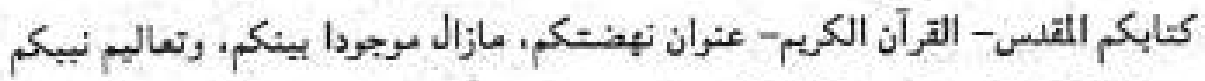

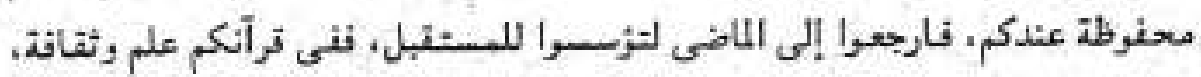
وتور معرفة، وسلام عليكم ياطلابثا إن كتا تى الماضي طلابكم: (r). وقلد خلف العرب العديد من كتب الصيدلة مثل ز) تذكرة ابن دارود) و (البهجة

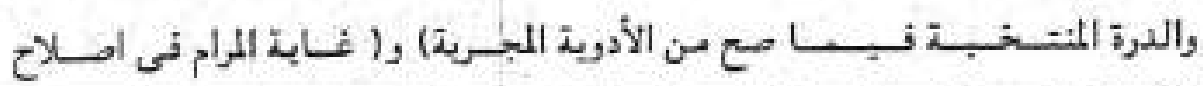

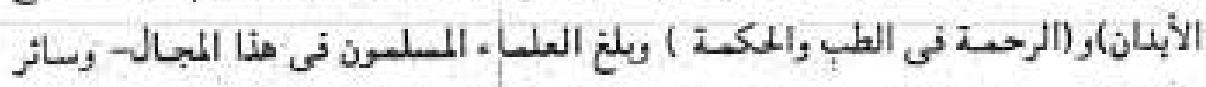

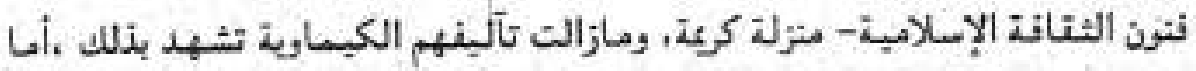
المولفات الأوربية فهي خير ثاهدة على إثـادتهم يفضل العرب المسلمين . ولايزال كثير

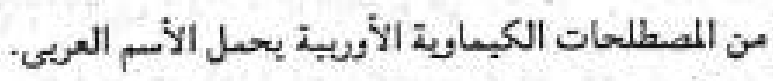

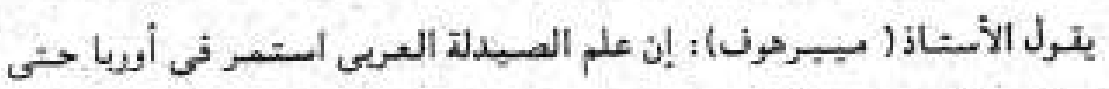
[r]. متتصن القرذ التاسع عشر

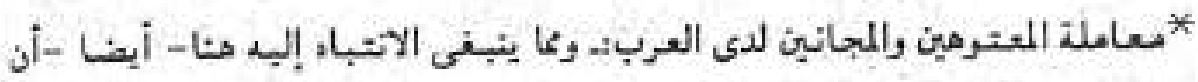

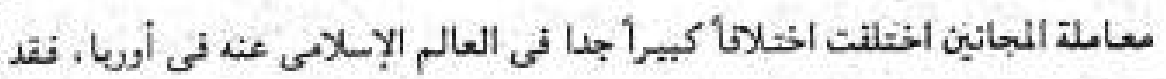

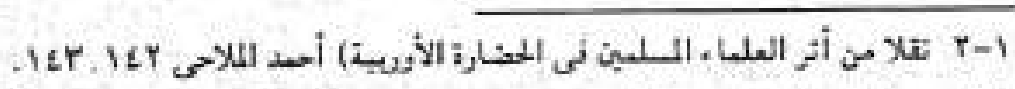

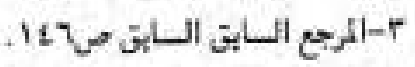




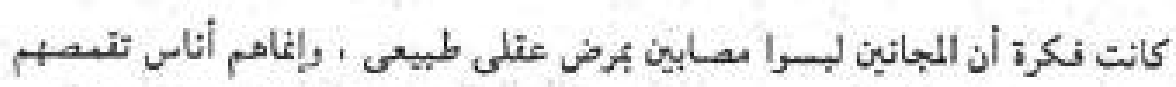

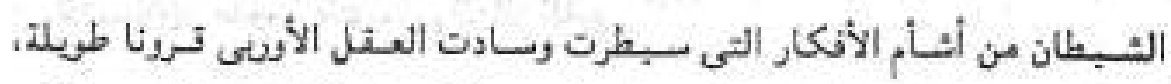

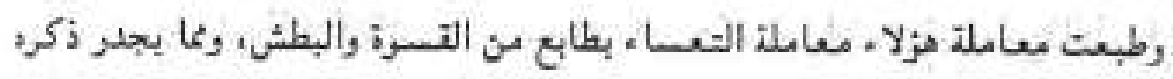

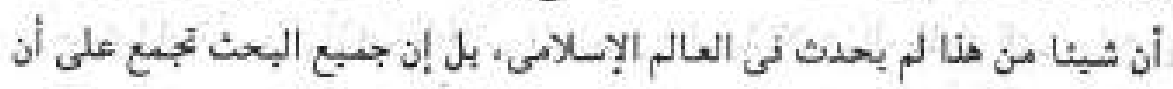

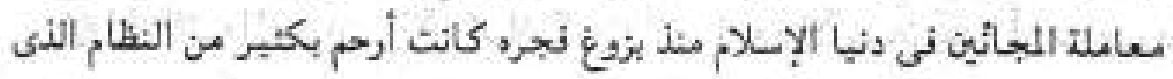

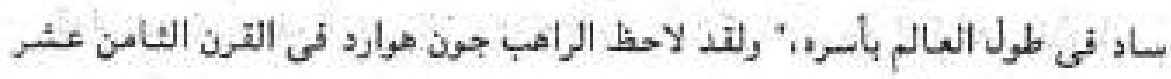

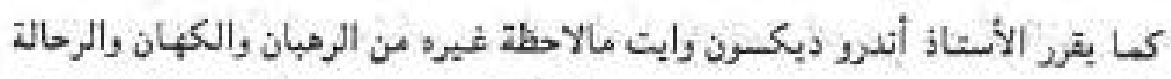

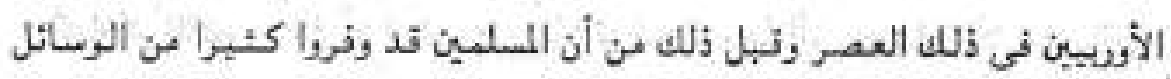

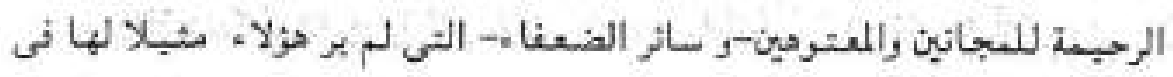

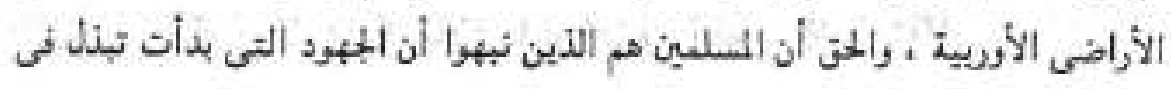

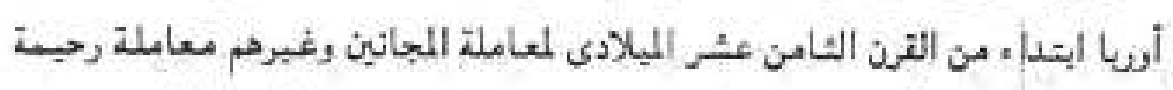

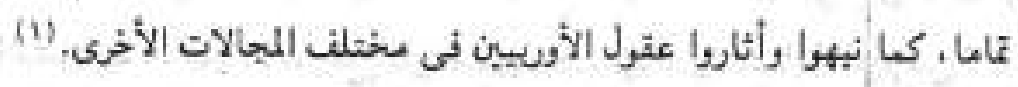
* أثر الكيمياء عند العرب فير النهضة الأوربية :-

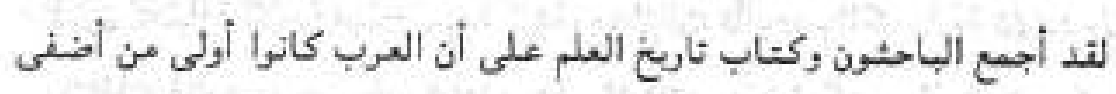

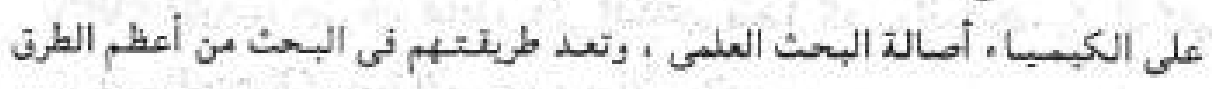

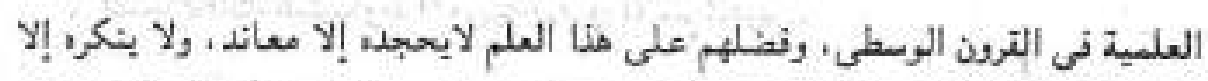

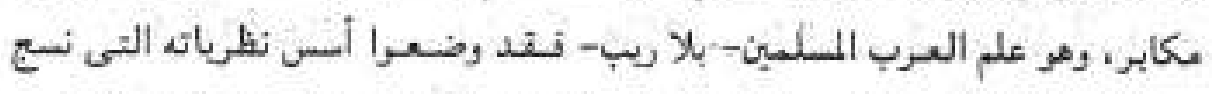

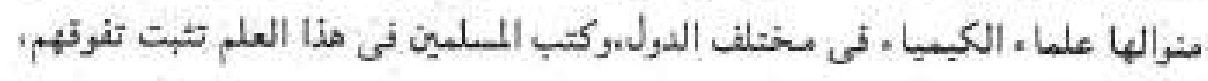

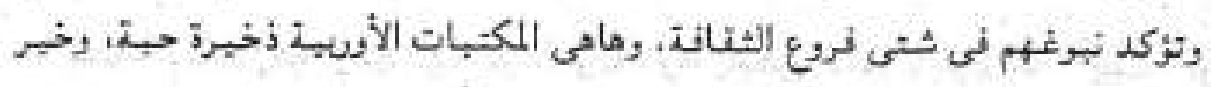

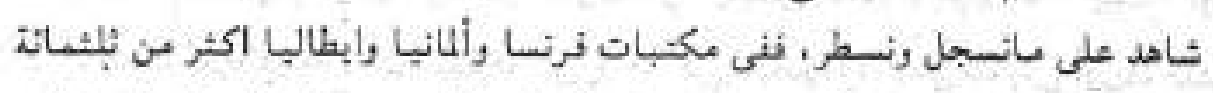

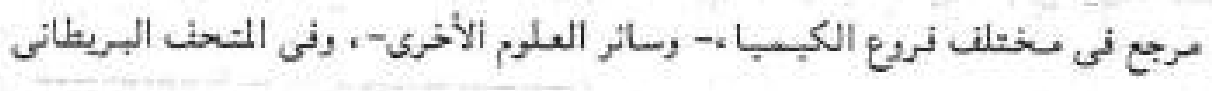

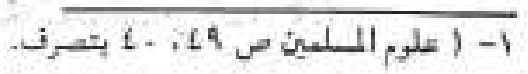




\section{ror}

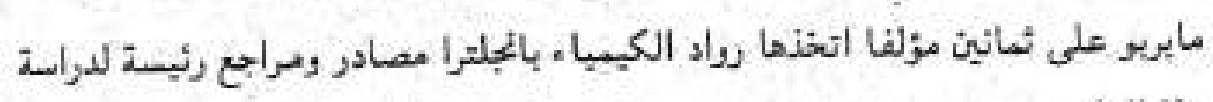
هلأ العلم.

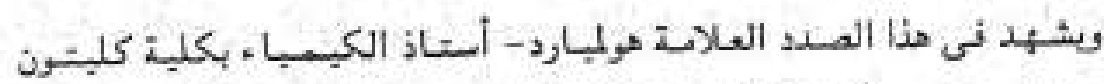

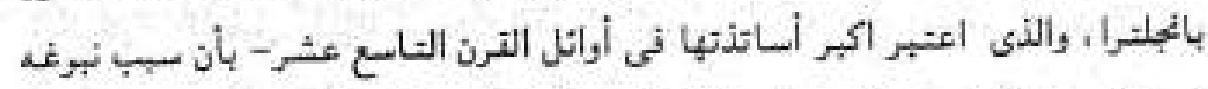
في الكيسيا - إثا يرجع إلى تعلمه اللفة العربية وإجادته البافة لها ودراسته للكيبياء.

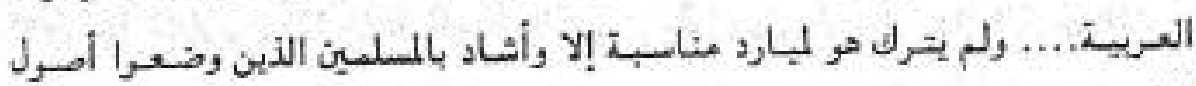

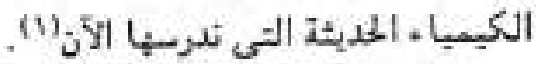

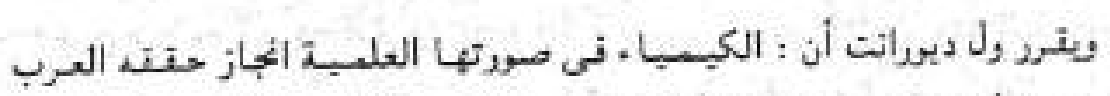

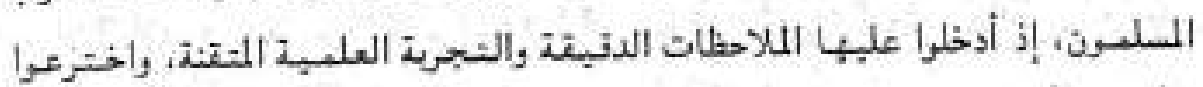

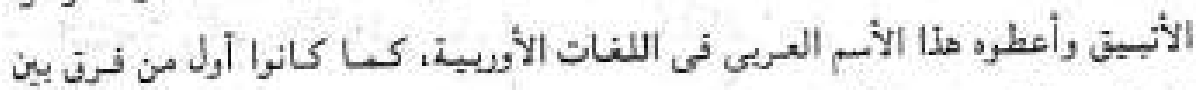

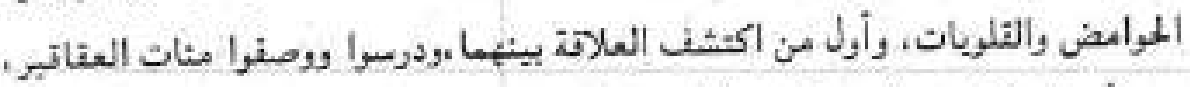

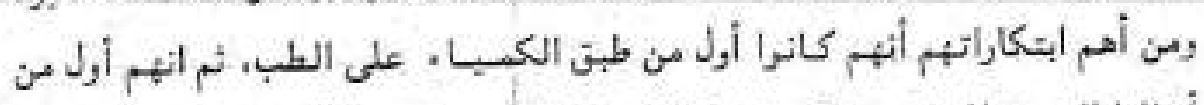

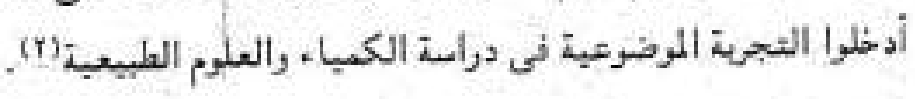

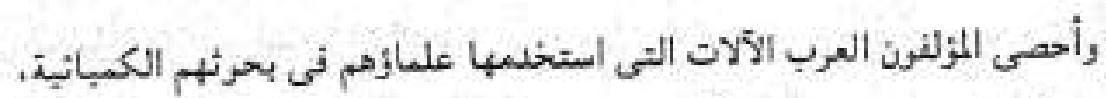

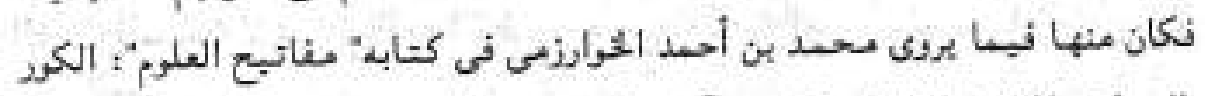

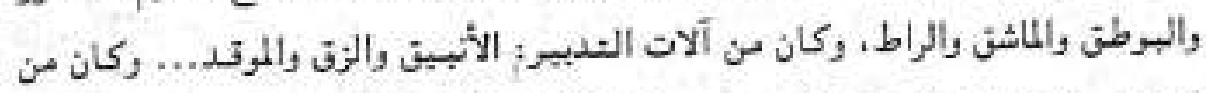
العتاتبر الثى الستخديوها في بعوثهيم الملح بأنواعبا المنتيلفة، والزاجات ( البللورات)

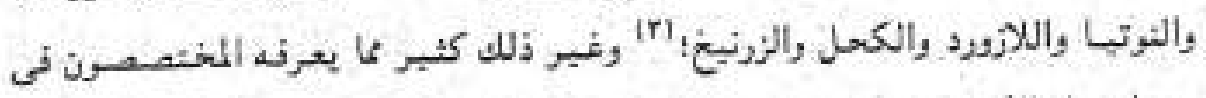

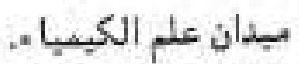

$$
\begin{aligned}
& \text { أ) }
\end{aligned}
$$

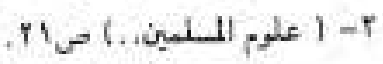

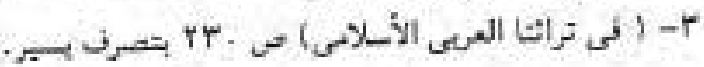

